Review

\title{
A Review of Various Fast Charging Power and Thermal Protocols for Electric Vehicles Represented by Lithium-Ion Battery Systems
}

\author{
Peter Makeen ${ }^{1,2, *(\mathbb{D} \text {, Hani A. Ghali }}{ }^{1}$ and Saim Memon $2,3, * \mathbb{D}$ \\ 1 Electrical Engineering Department, Faculty of Engineering, The British University of Egypt (BUE), \\ El-Sherouk 11837,Egypt; hani.amin@bue.edu.eg \\ 2 London Centre for Energy Engineering, Division of Electrical and Electronic Engineering, \\ School of Engineering, London South Bank University, London SE1 0AA, UK \\ 3 Department of Engineering and Technology, School of Computing and Engineering, \\ University of Huddersfield, West Yorkshire HD1 3DR, UK \\ * Correspondence: besadap@1sbu.ac.uk (P.M.); s.memon@1sbu.ac.uk (S.M.)
}

check for updates

Citation: Makeen, P.; Ghali, H.A.; Memon, S. A Review of Various Fast Charging Power and Thermal Protocols for Electric Vehicles Represented by Lithium-Ion Battery Systems. Future Transp. 2022, 2 , 281-299. https://doi.org/10.3390/ futuretransp2010015

Received: 3 January 2022

Accepted: 1 March 2022

Published: 4 March 2022

Publisher's Note: MDPI stays neutral with regard to jurisdictional claims in published maps and institutional affiliations.

Copyright: () 2022 by the authors Licensee MDPI, Basel, Switzerland. This article is an open access article distributed under the terms and conditions of the Creative Commons Attribution (CC BY) license (https:// creativecommons.org/licenses/by/ $4.0 /)$.

\begin{abstract}
Despite fast technological advances, the worldwide adoption of electric vehicles (EVs) is still hampered mainly by charging time, efficiency, and lifespan. Lithium-ion batteries have become the primary source for EVs because of their high energy density and long lifetime. Currently, several methods intend to determine the health of lithium-ion batteries fast-charging protocols. Filling a gap in the literature, a clear classification of charging protocols is presented and investigated here. This paper categorizes fast-charging protocols into the power management protocol, which depends on a controllable current, voltage, and cell temperature, and the material aspects charging protocol, which is based on material physical modification and chemical structures of the lithium-ion battery. In addition, each of the charging protocols is further subdivided into more detailed methodologies and aspects. A full evaluation and comparison of the latest studies is proposed according to the underlying parameterization effort, the battery cell used, efficiency, cycle life, charging time, and increase in surface temperature of the battery. The pros and cons of each protocol are scrutinized to reveal possible research tracks concerning EV fast-charging protocols.
\end{abstract}

Keywords: electric vehicles; fast charging; constant current constant voltage; multi-stage charging current; pulsating charging current; thermal management

\section{Introduction}

Presently, Electric Vehicles (EVs) are gaining strong momentum in the vehicle market due to their low price compared with conventional vehicles, low greenhouse gas (GHG) low emissions, low dependency on fossil fuels, low noise, and increasing climate and environmental awareness [1,2]. According to the report in [3], there were 10 million electric vehicles in the world at the end of 2020. In the first quarter of 2021, EV sales rose by $140 \%$ compared to the same period in 2020, despite the global pandemic (COVID-19).

In this article, an overview of different research tracks concerning EVs is presented; see Figure 1. We will briefly review the state of the art of the EV connection to energy source categories, charging standards, charging methodologies, the modeling of the lithium-ion battery, and scrutinize the various protocols of fast charging, presenting their pros and cons. 


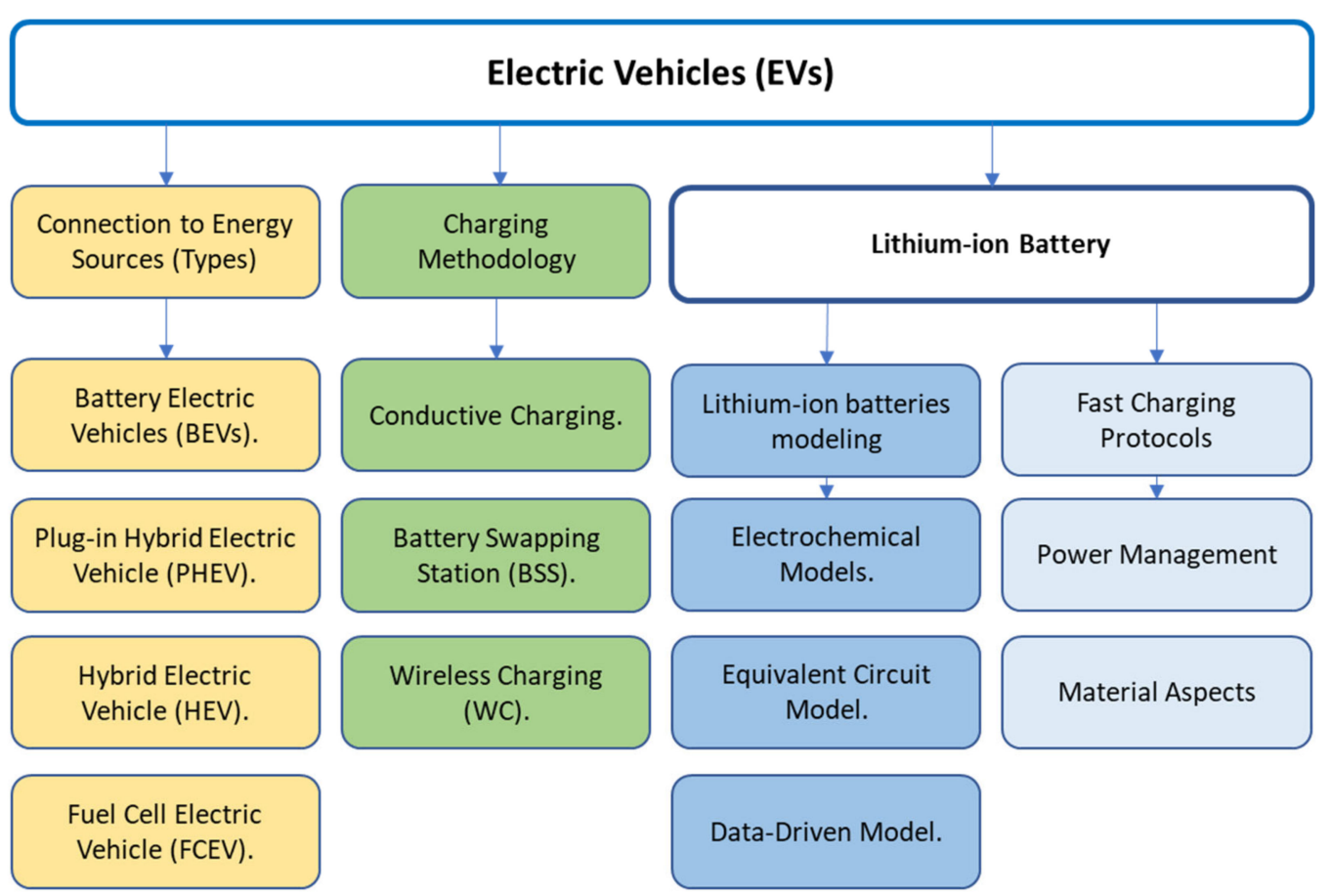

Figure 1. Overview of the electric vehicle (EV) research tracks.

\subsection{Electric Vehicle (EV) Overview}

EVs are divided into four main categories based on their connection to energy sources, namely plug-in hybrid electric vehicle (PHEV), hybrid electric vehicle (HEV), battery electric vehicle (BEV), and fuel cell electric vehicle (FCEV) [4,5]. PHEVs and HEVs depend on both electrical and internal combustion engines; BEV requires EVs that only run with electrical energy; and FCEVs use the on-board generation of hydrogen to reduce hydrogen storage and handling issues [6-8].

The authors in [9] predicted that around 130 million private chargers and 13 million public chargers will be needed by 2030 to fulfil the energy demand of different types of EVs. To facilitate this advancement, there is a direct need to invest in charging infrastructure. Chargers must be structured to charge EVs according to the standard set by international institutions such as the International Electrotechnical Commission (IEC), Society of Automotive Engineers (SAE), and CHAdeMO $[1,10]$. EV standards, according to IEC-62196, SAE-J1772 and CHAdeMO, are provided in [1,11-14]. Those standards are proposed in Table 1, and categorized based on the available maximum power rating, voltage, maximum rating current, and charging time.

Charging methodologies are classified into three main categories, namely conductive charging, wireless charging (WC), and a battery-swapping station (BSS) [8]. The battery can be charged anywhere, from an electric vehicle charging station (EVCS) to separate street chargers, workplace chargers, and private in-home chargers. The conductive charging technique depends on the advancement of the EV, which can have on-board and off-board properties. On-board chargers are widely known as AC chargers, which can be single-phase Level 1 and Level 2, as defined in SAE-J1772, and three-phase AC charging, as defined in SAE-J3068. Off-board chargers are referred to as DC chargers, which ensure higher charging current rates, as defined in SAE-J1772-Combo/CHAdeMO standards [15-17]. Wireless charging (WC) allows EVs to charge without any physical contact or cable connection between the supply and the battery $[18,19]$. Battery-swapping stations (BSS) are stations where an empty battery can be replaced with a fully charged battery within a few minutes $[20,21]$. 
Table 1. Charging rates of IEC standards, SAE standards, and CHAdeMO.

\begin{tabular}{|c|c|c|c|c|}
\hline Charging Levels & $\begin{array}{l}\text { Maximum Power } \\
\text { Rating }(\mathbf{k W})\end{array}$ & Voltage (V) & $\begin{array}{c}\text { Maximum Current } \\
\text { Rating (A) }\end{array}$ & Charging Time \\
\hline \multicolumn{5}{|c|}{ IEC-62196 Standard [1] } \\
\hline AC Level 1 & $\begin{array}{l}3.8 \\
7.6\end{array}$ & $\begin{array}{c}230-240 \mathrm{~V} \mathrm{AC} \\
480 \mathrm{~V} \text { AC }\end{array}$ & 16 & \multirow{4}{*}{ NA } \\
\hline AC Level 2 & $\begin{array}{c}7.6 \\
15.3\end{array}$ & $\begin{array}{c}230-240 \mathrm{~V} \mathrm{AC} \\
480 \mathrm{~V} \mathrm{AC}\end{array}$ & 32 & \\
\hline AC Level 3 & $\begin{array}{c}60 \\
120\end{array}$ & $\begin{array}{c}230-240 \mathrm{~V} \mathrm{AC} \\
480 \mathrm{~V} \text { AC }\end{array}$ & $32-250$ & \\
\hline DC & 400 & 600-1000 V DC & $250-400$ & \\
\hline \multicolumn{5}{|c|}{ SAE-J1772 Standards [22] } \\
\hline AC Level 1 & 1.9 & $120 \mathrm{~V} \mathrm{AC}$ & 16 & $\begin{array}{l}\text { PHEV: } 7 \mathrm{~h} \\
\text { BEV: } 17 \mathrm{~h}\end{array}$ \\
\hline AC Level 2 & $\begin{array}{c}3.3 \\
7\end{array}$ & $240 \mathrm{~V}$ AC & 80 & $\begin{array}{l}\text { PHEV: } 3 \mathrm{~h} \\
\text { BEV: } 7 \mathrm{~h} \\
\text { PHEV: } 1.5 \mathrm{~h} \\
\text { BEV: } 3.5 \mathrm{~h}\end{array}$ \\
\hline & 20 & & & $\begin{array}{l}\text { PHEV: } 22 \mathrm{~min} \\
\text { BEV: } 1.2 \mathrm{~h}\end{array}$ \\
\hline DC Level 1 & 40 & 200 to $500 \mathrm{~V} \mathrm{DC}$ & 80 & $\begin{array}{l}\text { PHEV: } 22 \mathrm{~min} \\
\text { BEV: } 1.2 \mathrm{~h}\end{array}$ \\
\hline DC Level 2 & Up to 100 & 200 to $500 \mathrm{~V} \mathrm{DC}$ & 200 & $\begin{array}{l}\text { PHEV: } 10 \mathrm{~min} \\
\text { BEV: } 20 \mathrm{~min}\end{array}$ \\
\hline \multicolumn{5}{|c|}{ CHAdeMO $[1,23]$} \\
\hline DC Fast Charging & 400 & $400 \mathrm{DC}$ & 200 & $20 \mathrm{~min}$ \\
\hline
\end{tabular}

Increasing the charging current accelerates battery aging disproportionally, leading to capacity and power fade and posing an unacceptable safety hazard during operation [24]. Several protocols have been developed to solve the trade-off between charging speed, battery surface temperature, and battery aging. In addition, car manufacturers have aimed for faster charging times by calculating charging time in $\mathrm{km} / \mathrm{min}$ to achieve a more user-oriented and comparative figure for different vehicle sizes. For example, the Tesla Model S has a charging speed of $16.3 \mathrm{~km} / \mathrm{min}$, which is considered the fastest BEV [24]. However, in an ideal case, the battery pack in an EV can accept high charging currents independent of the conditions present in the battery, while providing a long lifetime, lowcost maintenance and high sustainability. Unfortunately, these ideas usually pose several trade-offs, in reality, specifically a slow charging rate, which is considered to be one of the major limitations [24-26]. Consequently, researchers are currently aiming at understanding and improving the charging process of the battery pack, especially lithium-ion batteries.

\subsection{Lithium-Ion Battery}

Rechargeable Lithium-ion batteries are the intrinsic technology of EVs and they are commercialized for energy storage devices due to their high energy density, low selfdischarge rate, high efficiency, fast charging capability, and longer lifespan [27-29]. However, Li-ion batteries are sensitive to fast charging which accelerates the aging effect and capacity loss $[15,30]$. Hence, the charging processes can be influenced substantially by the manufacturers throughout realizing and implementing a specific charging protocol, that combines the charging time, capacity, and cycle life [31,32]. Section 2 will provide an overview of the various categories of charging protocols and their characteristics, pros, and cons. However, the experimental procedures for each protocol vary among the publications, which impedes a direct comparison. Due to the different cell types that have been used in the experiments, no independencies are revealed between the charging protocol 
and cell type. Consequently, it is very difficult to compare the performance of various charging protocols.

Before discussing the different categories of the charging protocols, the dynamic behaviour of the Lithium-ion battery has to be established using various models based on mathematical equations and/or collected data $[33,34]$. The most common models used are the electrochemical-mechanism model, which describes the internal chemical process of the battery, the equivalent circuit model which represents the chemical nature as electrical components, and the data-driven model which includes artificial neural network, support vector machine, black box, etc. [33,35-37]. Electrochemical models can describe the battery chemistry through the reactions that take place in the electrodes and the electrolyte deployed and can be classified as a Single Particle Model (SPM) [38,39], P2D model [40,41], a comprehensive capacity degradation model [42], as well as an Equivalent Circuit model such as the Rint model, PNGV model, Thevenin model, modified Thevenin model, RC first-order transient, RC second-order transient model, and RC cascaded transient model [25,43-45]. Finally, the Data-driven model consists of the black-box model that is considered as a linear and nonlinear mapping function of the terminal voltage, instead of providing a description of the electrochemical physics process of the battery, machine learning techniques with pattern recognition, clustering, and classification, and an artificial neural network, which are otherwise employed to predict the charging and discharging behaviour of the battery, etc., as stated in [33].

After an extensive literature review of different charging protocols, it was observed that a fair comparison of the various types of charging protocols has not yet been provided, because of the various lithium-ion batteries capacity used in each study. This paper reveals the comparison between the methodologies for each protocol, thereby providing a fair comparison. The main contributions of this review are as follows.

1. Clearly and systematically presents and classifies various charging protocols and the main controllable input and output parameters for each.

2. Reveals a full comparison between the sub charging methodologies of each charging protocol and the impact on the charging time, efficiency, lifetime, and energy loss.

3. Defines new up-to-date strategies depending on the power management, thermal management, and material aspects that are not mentioned in other literature reviews. In addition, a full identification of the pros and cons of each protocol may provide scope for the researchers to improve the existing protocols.

\section{Introduction of Fast Charging Protocols}

Fast charging protocols aim for a minimal charging time requirement, optimum efficiency, effective cycle life, and minimum charging loss. Researchers seek to eliminate the high C-rate charging and high depth of discharge (DOD) range which increase the loss of active material and reform the solid electrolyte interphase (SEI) at the surface of the electrode, hence resulting in an increase in the internal impedance and minimizing the capacity of the battery [46-48]. In addition, researchers recommended avoiding overcharge and over-discharge of the battery, which can cause unwanted heating inside the battery, therefore cracking the SEI and loss of active area inside the lithium-ion battery, and minimizing the number of ions participating in the electrochemical reaction, respectively $[49,50]$. Consequently, the efficiently designed and high-quality charging protocol not only reduces the charging time but will also improve the performance of the battery, energy conversion efficiency, lifespan, and reduce energy loss.

This paper delineates the main fast-charging protocols for lithium-ion batteries, as expressed in Figure 2. The protocols can be split into power management, which depends on the topology of applying the voltage and current during the charging process; thermal management, which manipulates the temperature of the lithium-ion battery while charging; and the material aspects which pertain to the electrolyte modifications (concentrated electrolyte and low viscosity additives). The most up-to-date articles in each category are discussed in the following sections. 


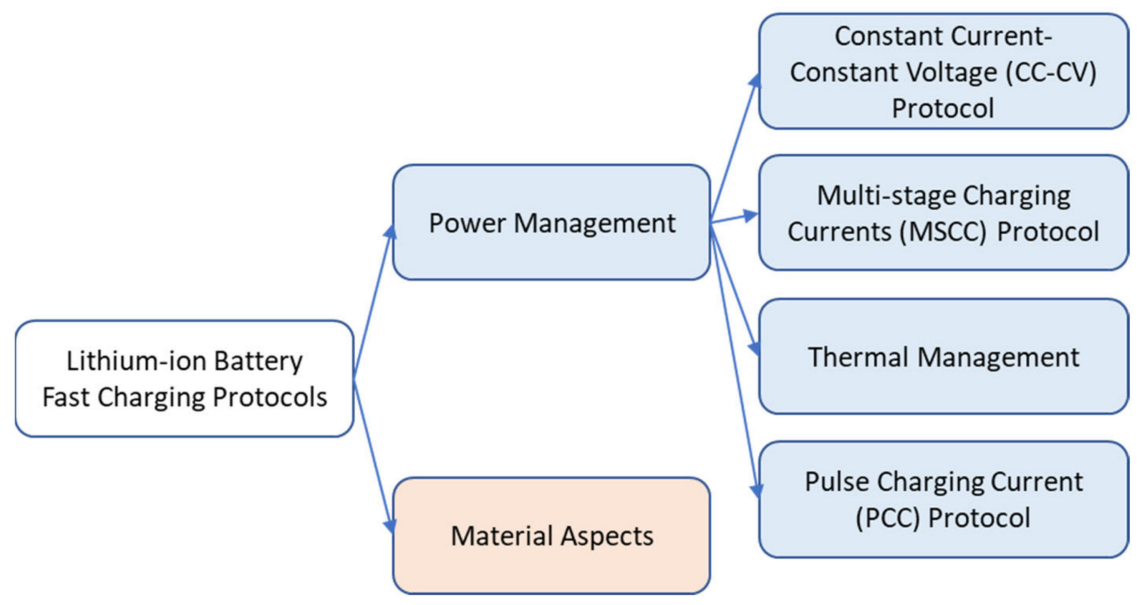

Figure 2. Main fast-charging protocols of the Lithium-ion battery.

\section{Power Management Charging Protocol}

The power-management charging protocol is based on charging the lithium-ion battery with various current and voltage topologies to ensure fast charging, minimum charging loss, high efficiency, and increased lifespan. An investigation for each protocol is introduced in the following sections.

\subsection{Constant Current Constant Voltage (CC-CV) Protocol}

$\mathrm{CC}-\mathrm{CV}$ is considered to be the traditional charging protocol for lithium-ion batteries. CC-CV methodology is based on charging the battery by a constant rated charging current until the voltage reaches the cut-off value and then the voltage is held constant while the current decays to the minimum value as expressed in Figure 3. This protocol is efficient with a battery management system (BMS) [51], easy to implement, has simple requirements, and avoids overcharging due to the constant voltage mode. In addition, CC-CV is considered as the main contributor in the centralized electric-vehicle charging stations in minimizing the queuing delay per EV, especially during peak hours [51]. However, it is conservative because of the long charging time while gradually reducing the current density to $0.1 \mathrm{C}$ where the $\mathrm{C}$-rate is a measure of the rate at which a battery is charged/discharged relative to its maximum capacity [52], low efficiency, and short battery runtime [53,54]. The authors in [55] revealed that the CV charging stage can cause server degradation whenever the voltage exceeds the cutoff voltage.

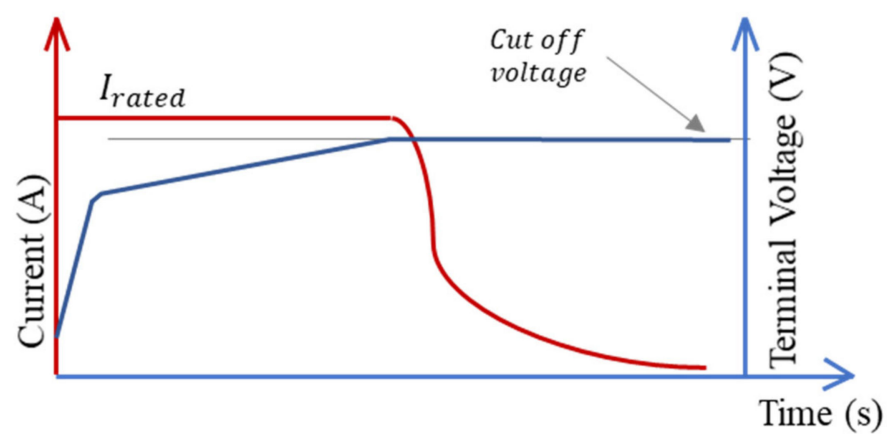

Figure 3. Schematic diagram of the Constant Current Constant Voltage (CC-CV) Protocol.

\subsection{Multi-Stage Charging Currents (MSCC) Protocol}

Researchers are seeking protocols to reduce the charging time and degradation compared to the CC-CV methodology. In the multi-stage charging currents protocol, the battery is charged by a multi-stage application of different currents and the lifetime extends without degradation impact. Many algorithms and techniques have been implemented for 
multi-stage constant current charging of the lithium-ion battery to reduce the charging time, reduce the energy loss and improve the charging efficiency. However, it is time-consuming to find the optimal charging strategy by means of charging and discharging experiments.

The charging process in [56] is split into $n$ stages of constant current (CC) $\left[I_{1}, I_{2}, \ldots\right.$, $\left.I_{\mathrm{n}}\right]$, which are combined with $n$ voltage thresholds $\left[\mathrm{V}_{1}, \mathrm{~V}_{2}, \ldots, \mathrm{V}_{n}\right]$, which control the end of each CC stage. An optimization algorithm is formulated by the fmincon MATLAB function to estimate the parameters of the MSCC protocol, where the number of stages is set to $n=10$. MSCC is investigated at different chosen temperatures of $5{ }^{\circ} \mathrm{C}, 25^{\circ} \mathrm{C}$, and $45^{\circ} \mathrm{C}$ representing a cold, mild, and hot climate, respectively. The comparison between the MSCC and CC-CV is implemented via five main scenarios, as presented in Table 2 below. The proposed scenarios successfully reduced the degradation compared to $\mathrm{CC}-\mathrm{CV}$ references.

An optimal charging pattern is implemented in [57], of five MSCC, where the Grey Wolf Optimization algorithm (GWOA) is used to find the optimal charging current for each stage. An improvement in the charging time, maximum temperature rise, and charging efficiency are ensured in this article. The advantages of the GWOA include few parameters, easy implementation, and a special capability to strike the balance between exploration and exploitation during the searching process. The charging current stage using GWOA changes whenever the battery voltage reaches the cut-off voltage and these procedures are repeatable until the change in voltage is minimized as shown in Figure 4a.

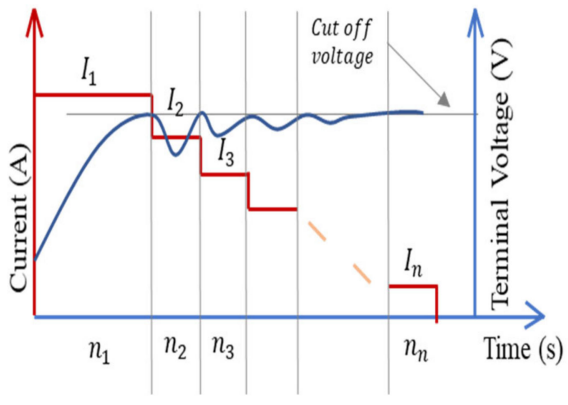

(a)

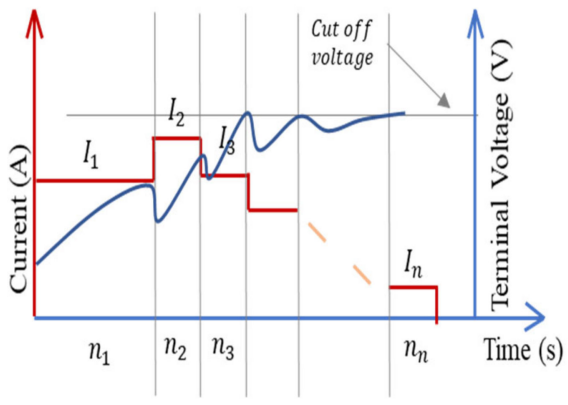

(c)

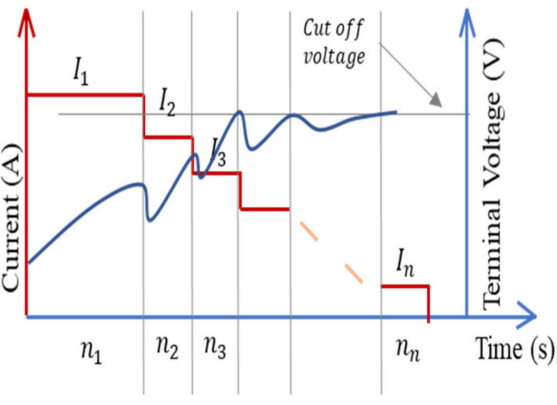

(b)

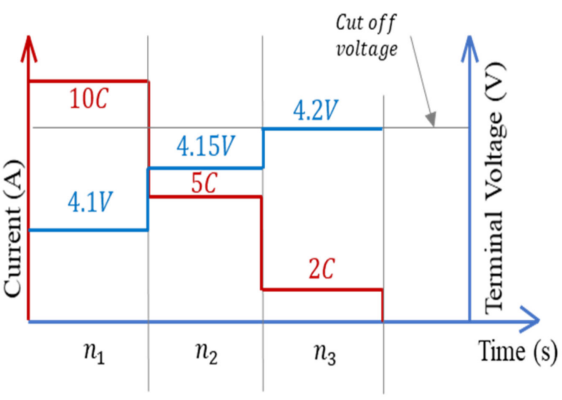

(d)

Figure 4. Schematic diagram of the Multi-Stage Charging Current (MSCC) Protocol where (a) The charging current stage changes whenever the battery voltage reaches the cut-off voltage, (b) the Hierarchical technique (HT), (c) the Conditional random technique (CRT), and (d) multilevel multistage constant current-constant voltage superfast charging (ML MCC-CV) methodology.

A multistage constant current-constant voltage protocol (MCCCV), based on the particle swarm optimization algorithm, is proposed in [58], where the following three strategies are proposed: a fast charging for motorway driving (aging loss of the battery is not considered $\beta=1$ ), minimum aging charging for family use $(\beta=0)$, and a balanced charging for daily use which is expressed using a Pareto frontier boundaries plot. In MCCCV procedures, the battery is first charged at a constant current until the voltage reaches a cut-off voltage, then a new set of charging currents is applied accordingly, until 
the SOC of the battery reaches $\geq 90 \%$, at which point it reaches the constant voltage stage. Additionally, the authors in [59] used the Particle Swarm Optimisation (PSO) algorithm with strategies presented in [58].

The Taguchi-orthogonal method was employed in [60] to search for an optimal fast charging five stage pattern. The Taguchi method is based on experimental analysis, so as to avoid complicating the modeling of the lithium-ion battery.

In [61], the Taguchi-orthogonal-based particle swarm optimization (TPSO) algorithm was utilized, using four MSCC protocols and the results were compared with five MSCC protocols. It was concluded that four or five MSCCs do not have a significant impact on the charging time and efficiency. However, the battery cycle life decreased when using four MSCC protocols with respect to the CC-CV protocol.

The multi-objective particle swarm optimization (MOPSO) method based on the Pareto front was employed in [62]. The optimum solution is selected using the technique for order of preferences by similarity to ideal solution (TOPSIS).

In $[34,63]$ a meta-heuristic algorithm based on the Cuckoo Optimization Algorithm was utilized in the fast charging of a lithium-polymer ion battery. COA is applied via two main techniques: The Hierarchical technique (HT) and the Conditional random technique (CRT) as shown in Figure $4 b, c$ respectively. The HT was obtained by applying hierarchical stepping-down variable constant currents during the charging process, while the CRT was based on the conditional randomness of the cuckoo optimization algorithm which chooses the values of the stage currently lying within the boundaries.

To prevent the voltage from rising to the cut-off voltage level during the charging process, multilevel multistage constant current-constant voltage superfast charging (ML MCC-CV) methodology was implemented in [64]. The initial charge mode, in this model, is set to trickle mode to avoid battery damage. When the voltage of the battery is within the normal operating range $(\geq 3 \mathrm{~V})$ ML MCC-CV charging starts as shown in Figure $4 \mathrm{~d}$, where the charging voltage and current are set to be $4.1 \mathrm{~V}$ and $10 \mathrm{C}$, respectively. Whenever the battery voltage reaches $\geq 4.1 \mathrm{~V}$, a charge voltage of $4.15 \mathrm{~V}$ and CC of $5 \mathrm{C}$ are applied. Finally, when the voltage reaches $\geq 4.15 \mathrm{~V}$, a charging voltage of $4.2 \mathrm{~V}$ and $\mathrm{CC}$ of $2 \mathrm{C}$ is implemented until the end of charging.

Researchers use various methodologies to study the charging process with different models to represent the dynamic behaviour of the lithium-ion battery, where the output of each research paper can be represented in the charging time, energy consumption, charging efficiency performance, maximum applied current, cycling, and temperature rise, which are summarized in Table 2.

In [65] a large-scale EV battery with a capacity of $50 \mathrm{kw}$ was charged from $20 \%$ to $90 \%$ SOC using the constant power constant voltage (CPCV) methodology and the results were compared with the conventional CC-CV charging protocol. It was concluded that the optimal power charging can reduce the energy loss and $9 \%$ of the cost compared to the existing conventional fast-charging mode.

Such power management approaches based on MSCC are often motivated by reducing heat generation, avoiding lithium plating, avoiding overcharging, and reducing mechanical stresses when the diffusion of $\mathrm{Li}+$ ions is constrained [66]. However, the MSCC protocol requires a full estimation of all the internal equivalent parameters of the electric circuit used in modelling [34,67]. 
Table 2. Comparison between algorithms presented in the literature survey using the Multi-stage charging current (MSCC) protocol, and Thermal Management Protocol.

\begin{tabular}{|c|c|c|c|c|c|c|c|c|c|c|c|c|}
\hline & Type & & Battery & Circuit & $\begin{array}{l}\text { Charging } \\
\text { Time (min) }\end{array}$ & $\begin{array}{c}\text { Maximum } \\
\text { Charging } \\
\text { Current (A) }\end{array}$ & $\begin{array}{l}\text { No of } \\
\text { Stages }\end{array}$ & $\underset{(\%)}{\operatorname{SOC}_{f}}$ & $\begin{array}{l}\text { Charging } \\
\text { Efficiency } \\
(\%)\end{array}$ & $\begin{array}{l}\text { Charging } \\
\text { Loss (J) }\end{array}$ & Cycling & $\begin{array}{l}\text { Temperature } \\
\text { Rise }\left({ }^{\circ} \mathrm{C}\right)\end{array}$ \\
\hline \multirow{10}{*}{$\begin{array}{c}\text { Numerical } \\
\text { optimiza- } \\
\text { tion } \\
{[56]}\end{array}$} & \multirow{2}{*}{ Case A $25^{\circ} \mathrm{C}$} & $\mathrm{CC}-\mathrm{CV}$ & \multirow{10}{*}{$\begin{array}{l}\text { INR18650HG2 } \\
\text { from LG, } \\
3 \mathrm{Ah}\end{array}$} & \multirow{10}{*}{$\begin{array}{l}\text { Coupled } \\
\text { Electro- } \\
\text { thermal } \\
\text { model }\end{array}$} & 61 & $1.33 \mathrm{C}$ & --- & 96.2 & N/A & N/A & 330 & N/A \\
\hline & & MSCC & & & 65 & $1.917 \mathrm{C}$ & 10 & 96.8 & N/A & N/A & $700-800$ & N/A \\
\hline & $C=0=820^{\circ}$ & $\mathrm{CC}-\mathrm{CV}$ & & & 43 & $1.66 \mathrm{C}$ & -- & 96.2 & N/A & N/A & 330 & N/A \\
\hline & \multirow{5}{*}{$\begin{array}{l}\text { Case C } 25^{\circ} \mathrm{C} \\
\text { Case D } 5{ }^{\circ} \mathrm{C}\end{array}$} & MSCC & & & 52 & $3 \mathrm{C}$ & 10 & 93.5 & N/A & N/A & 450 & N/A \\
\hline & & CC-CV & & & 46 & $1.67 \mathrm{C}$ & -- & 83.3 & N/A & N/A & 600 & N/A \\
\hline & & MSCC & & & 37 & $3 \mathrm{C}$ & 5 & 78.4 & N/A & N/A & 1200 & N/A \\
\hline & & $\mathrm{CC}-\mathrm{CV}$ & & & 66 & $1.33 \mathrm{C}$ & --. & 91.4 & N/A & N/A & 100 & N/A \\
\hline & & MSCC & & & 91 & $1.167 \mathrm{C}$ & 10 & 90.4 & N/A & N/A & 400 & N/A \\
\hline & \multirow{2}{*}{ Case E $45^{\circ} \mathrm{C}$} & CC-CV & & & 53 & $1.33 \mathrm{C}$ & $\ldots$ & 97.8 & N/A & N/A & $900-1000$ & N/A \\
\hline & & MSCC & & & 44 & $2.33 \mathrm{C}$ & 10 & 95.1 & N/A & N/A & 1200 & N/A \\
\hline \multirow{8}{*}{\multicolumn{2}{|c|}{$\begin{array}{l}\text { Grey Wolf optimization algorithm } \\
{[57]}\end{array}$}} & 2C-CC-CV & \multirow{8}{*}{$\begin{array}{l}\text { SAMSUNG } \\
\text { INR18650- } \\
\text { 25R Li-Ion } \\
\text { Battery }\end{array}$} & \multirow{8}{*}{$\begin{array}{l}\text { Thevenin } \\
\text { equivalent } \\
\text { circuit }\end{array}$} & 66 & $2 \mathrm{C}$ & --- & 98.43 & 98.31 & N/A & N/A & $\sim+2 \mathrm{~K}$ \\
\hline & & 1C-CC-CV & & & 97 & $1 \mathrm{C}$ & --- & 100 & 98.4 & 1363.04 & 167 & $\sim+1.75 \mathrm{~K}$ \\
\hline & & Case-1 & & & 92 & $0.8292 \mathrm{C}$ & 5 & 98.45 & 98.87 & 1133.91 & 300 & $\sim+1.75 \mathrm{~K}$ \\
\hline & & Case-2 & & & 93 & $0.832 \mathrm{C}$ & 5 & 98.46 & 98.82 & 1142.4 & N/A & $\sim+1.75 \mathrm{~K}$ \\
\hline & & Case-3 & & & 85 & $1 \mathrm{C}$ & 5 & 98.79 & 98.69 & 1334.99 & N/A & $\sim+2.1 \mathrm{~K}$ \\
\hline & & Case-4 & & & 89 & $0.9092 \mathrm{C}$ & 5 & 98.48 & 98.7 & 1239.26 & N/A & $\sim+2 \mathrm{~K}$ \\
\hline & & Case-5 & & & 91 & $0.8692 \mathrm{C}$ & 5 & 98.01 & 98.79 & 1175.86 & N/A & $\sim+1.9 \mathrm{~K}$ \\
\hline & & Case-6 & & & 93 & $0.822 \mathrm{C}$ & 5 & 98.46 & 98.81 & 1132.1 & $\mathrm{~N} / \mathrm{A}$ & $\sim+1.75 \mathrm{~K}$ \\
\hline \multirow{6}{*}{$\begin{array}{l}\text { Adaptive } \\
\text { MSCC [58] }\end{array}$} & \multirow{3}{*}{$\begin{array}{l}\text { Fast Charging } \\
\qquad(\beta=1)\end{array}$} & CC-CV & \multirow{6}{*}{$\begin{array}{l}\text { NCR18650B } \\
\text { battery }\end{array}$} & \multirow{6}{*}{$\begin{array}{c}1 \mathrm{RC} \\
\text { transient }\end{array}$} & 52.7 & $1 \mathrm{C}$ & $-\ldots$ & N/A & N/A & N/A & N/A & $+5.1^{\circ} \mathrm{C}$ \\
\hline & & CC-CV & & & 68.383 & $0.75 \mathrm{C}$ & $\ldots$ & N/A & N/A & N/A & N/A & $+3^{\circ} \mathrm{C}$ \\
\hline & & MCCCV & & & 52.7 & $1 \mathrm{C}$ & NA & $\mathrm{N} / \mathrm{A}$ & N/A & N/A & N/A & $+5.1^{\circ} \mathrm{C}$ \\
\hline & \multirow{3}{*}{$\begin{array}{c}\begin{array}{c}\text { Minimum-aging } \\
(\beta=0) \\
\text { Balanced charging } \\
(\beta=0.014)\end{array}\end{array}$} & $\mathrm{MCCCV}$ & & & 200 & $0.25 \mathrm{C}$ & NA & $\mathrm{N} / \mathrm{A}$ & $\mathrm{N} / \mathrm{A}$ & N/A & N/A & $+0.35^{\circ} \mathrm{C}$ \\
\hline & & $\mathrm{MCCCV}$ & & & 58 & $0.7836 \mathrm{C}$ & NA & 99.013 & N/A & N/A & $\mathrm{N} / \mathrm{A}$ & $+3.5^{\circ} \mathrm{C}$ \\
\hline & & $\mathrm{CC}-\mathrm{CV}$ & & & 102.77 & $0.5 \mathrm{C}$ & --- & N/A & $\mathrm{N} / \mathrm{A}$ & N/A & $\mathrm{N} / \mathrm{A}$ & $+1.5^{\circ} \mathrm{C}$ \\
\hline \multirow{5}{*}{\multicolumn{2}{|c|}{$\begin{array}{l}\text { Taguchi-orthogonal based Particle } \\
\text { Swarm Optimisation (TPSO) [61] }\end{array}$}} & CC-CV & Sanyo & \multirow{5}{*}{ N/A } & 119 & $0.7 \mathrm{C}$ & 0 & 99.5 & 99.10 & N/A & 280 & $\sim+2.75^{\circ} \mathrm{C}$ \\
\hline & & ECCCV & UR14500P & & 114 & $0.8036 \mathrm{C}$ & 0 & 98.7 & 98.93 & N/A & $\mathrm{N} / \mathrm{A}$ & $\sim+1.5^{\circ} \mathrm{C}$ \\
\hline & & MSCC & $840 \mathrm{mAh}$ & & 67 & $1.262 \mathrm{C}$ & 4 & 94.7 & 98.97 & N/A & 190 & $\sim+3.5^{\circ} \mathrm{C}$ \\
\hline & & MSCC & Sanyo & & 51 & $1.44 \mathrm{C}$ & 5 & & 98.91 & N/A & N/A & N/A \\
\hline & & $\mathrm{CC}-\mathrm{CV}$ & $\begin{array}{l}\text { UR14500P } \\
2200 \mathrm{mAh}\end{array}$ & & 118 & $1.44 \mathrm{C}$ & 0 & & 98.54 & N/A & $\mathrm{N} / \mathrm{A}$ & N/A \\
\hline $\begin{array}{r}\text { Multi-objec } \\
\text { optimisat }\end{array}$ & $\begin{array}{l}\text { e particle swarm } \\
\text { (MOPSO) [62] }\end{array}$ & MSCC & $\begin{array}{c}\mathrm{LiFePO}_{4} \\
\text { battery } \\
8 \mathrm{Ah} \text { and } \\
3.2 \mathrm{~V}\end{array}$ & $\begin{array}{c}1 \mathrm{RC} \\
\text { transient }\end{array}$ & 25.567 & $4.925 \mathrm{C}$ & 8 & $\mathrm{~N} / \mathrm{A}$ & N/A & N/A & $\mathrm{N} / \mathrm{A}$ & $+4.1^{\circ} \mathrm{C}$ \\
\hline & & CC-CV_0.1C & & & 59.4 & $1.55 \mathrm{C}$ & --. & 94.1 & 93.3 & N/A & N/A & $+20.3^{\circ} \mathrm{C}$ \\
\hline Taguchi-ortl & onal method [60] & CC-CV_0.2C & $3150 \mathrm{mAh}$ & 1 Resistor + & 49.37 & $1.55 \mathrm{C}$ & --- & 92.3 & 93 & N/A & $\mathrm{N} / \mathrm{A}$ & NA \\
\hline & & MSCC̄_1 & $3150 \mathrm{mAh}$ & 1 Impedance & 54.22 & $1.55 \mathrm{C}$ & 5 & 93 & 93.9 & N/A & $\mathrm{N} / \mathrm{A}$ & $+19.2{ }^{\circ} \mathrm{C}$ \\
\hline & & MSCC_2 & & & 55.47 & $2 \mathrm{C}$ & 5 & 93.1 & 91.1 & N/A & $\mathrm{N} / \mathrm{A}$ & $+28.5^{\circ} \mathrm{C}$ \\
\hline & & 1C-CC-CV & & & 50 & $1 \mathrm{C}$ & N/A & $\mathrm{N} / \mathrm{A}$ & N/A & N/A & N/A & $\sim+6^{\circ} \mathrm{C}$ \\
\hline & & 2C-CC-CV & & & $\sim 29.2$ & $2 \mathrm{C}$ & N/A & N/A & N/A & N/A & N/A & $\sim+18^{\circ} \mathrm{C}$ \\
\hline & & $\begin{array}{l}\text { Minimum } \\
\text { charging time }\end{array}$ & & & 27.43 & $2 \mathrm{C}$ & N/A & N/A & N/A & N/A & Decays $0.8 \%$ & $\sim+18^{\circ} \mathrm{C}$ \\
\hline Particle Swar & $\begin{array}{l}\text { Dptimisation (PSO) } \\
\text { 59] }\end{array}$ & $\begin{array}{c}(\beta=1) \\
\text { Minimum Aging }\end{array}$ & $\begin{array}{l}\text { l8,650 } \\
\text { LI-ION }\end{array}$ & $\begin{array}{l}\text { MRC } \\
\text { transient }\end{array}$ & & & & & & & & \\
\hline & & $\begin{array}{l}\text { Minimum Aging } \\
\text { charging }\end{array}$ & CELLS & & $\sim 60$ & $0.077 \mathrm{C}$ & N/A & $\mathrm{N} / \mathrm{A}$ & $\mathrm{N} / \mathrm{A}$ & N/A & $\begin{array}{c}\text { Decays } \\
0.5576 \%\end{array}$ & $\sim+0.04{ }^{\circ} \mathrm{C}$ \\
\hline & & $\begin{array}{l}\text { Balanced charging } \\
\quad(\beta=0.0113)\end{array}$ & & & 51.832 & $0.89 \mathrm{C}$ & N/A & N/A & N/A & N/A & $\begin{array}{c}\text { Decays } \\
0.6276 \%\end{array}$ & $\sim+4{ }^{\circ} \mathrm{C}$ \\
\hline & & CC-CV & Lithium & & 118.33 & $1 \mathrm{C}$ & --- & 100 & NA & 1127.667 & $\mathrm{~N} / \mathrm{A}$ & $\mathrm{N} / \mathrm{A}$ \\
\hline Cuckoo Optim & tion Algorith (COA) & $\begin{array}{l}\text { The hierarchical } \\
\text { technique (HT) }\end{array}$ & $\begin{array}{l}\text { Lithum } \\
\text { Polymer ion }\end{array}$ & $2 \mathrm{RC}$ & 96.92 & $1 \mathrm{C}$ & 5 & 100 & $\mathrm{CC}-\mathrm{CV}+8 \%$ & 1039.9 & $\mathrm{~N} / \mathrm{A}$ & N/A \\
\hline Cискоо ортіті & $4,63]$ & $\begin{array}{l}\text { The conditional } \\
\text { random technique } \\
\text { (CRT) }\end{array}$ & $\begin{array}{l}\text { battery } \\
1000 \mathrm{mAh}\end{array}$ & transient & 91.767 & $1 \mathrm{C}$ & 5 & 100 & $\begin{array}{l}\text { CC-CV + } \\
14.1 \%\end{array}$ & 1010.3 & N/A & N/A \\
\hline & & CC-CV & $\begin{array}{l}\text { Samsung } \\
\text { INR18650- }\end{array}$ & & 85 & $1 \mathrm{C}$ & --- & 100 & $\mathrm{~N} / \mathrm{A}$ & N/A & $\mathrm{N} / \mathrm{A}$ & $+7.5^{\circ} \mathrm{C}$ \\
\hline $\begin{array}{l}\text { Constant Te } \\
\text { Voltage (C) }\end{array}$ & $\begin{array}{l}\text { erature Constant } \\
\text { V) protocol [68] }\end{array}$ & & $25 \mathrm{R}$ & $\begin{array}{l}\text { model- } \\
\text { Second- }\end{array}$ & & & & & & & & \\
\hline & & $\mathrm{CT}-\mathrm{CV}$ & $\begin{array}{l}\text { cylindrical } \\
\text { cell }\end{array}$ & $\begin{array}{l}\text { order } \\
\text { thermal } \\
\text { model }\end{array}$ & 69.5 & $2 \mathrm{C}$ & --- & 100 & N/A & N/A & $\mathrm{N} / \mathrm{A}$ & $+7.5^{\circ} \mathrm{C}$ \\
\hline & & Real time PMP & Panasonic & Thermal & 18 & $5 \mathrm{C}$ & -- & $\begin{array}{c}20 \text { to } \\
70\end{array}$ & N/A & N/A & N/A & $\sim+6^{\circ} \mathrm{C}$ \\
\hline $\begin{array}{r}\text { Pontryagin's } \\
\text { (I }\end{array}$ & $\begin{array}{l}\text { inimum Principle } \\
\text { P) [69] }\end{array}$ & CC-CV & NCR18650PF & $\begin{array}{l}\text { Thermal } \\
\text { Dynamics }\end{array}$ & 16 & $1.61 \mathrm{C}$ & -- & $\begin{array}{l}20 \text { to } \\
70\end{array}$ & N/A & N/A & $\mathrm{N} / \mathrm{A}$ & $\sim+5.5^{\circ} \mathrm{C}$ \\
\hline Genetic Algc & hm (GA) optimal & $\mathrm{CC}$ & LiNMC, & & 40.05 & $0.5 \mathrm{C}$ & --- & 95.34 & $\mathrm{~N} / \mathrm{A}$ & 0.77 & $\mathrm{~N} / \mathrm{A}$ & $+2.13^{\circ} \mathrm{C}$ \\
\hline chargin & trategy [70] & $\begin{array}{l}\text { Optimal } \\
\text { Improvement }\end{array}$ & $5 \mathrm{Ah}, 3.6 \mathrm{~V}$ & transient & 36.1 & $0.5 \mathrm{C}$ & --- & 95.34 & $\mathrm{~N} / \mathrm{A}$ & 0.7 & $\mathrm{~N} / \mathrm{A}$ & $+1.91^{\circ} \mathrm{C}$ \\
\hline & 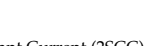 & High-low profile & $\mathrm{A} 12326,650$ & & 30 & $\begin{array}{l}2.6 \mathrm{C} \text { to } \\
0.6 \mathrm{C}\end{array}$ & 2 & 80 & 98.1 & 6.62 & $\mathrm{~N} / \mathrm{A}$ & $\sim+8{ }^{\circ} \mathrm{C}$ \\
\hline Iwo Stage Cor & $\begin{array}{l}\text { ant (urrent }(2 \mathrm{SCC}) \\
71]\end{array}$ & Low high profile & $\begin{array}{l}\text { graphite } \\
\text { cylindrical } \\
\text { battery cell }\end{array}$ & N/A & 30 & $\begin{array}{l}0.6 \mathrm{C} \text { to } \\
2.6 \mathrm{C}\end{array}$ & 2 & 80 & 95.1 & 6.83 & N/A & $\sim+8.5^{\circ} \mathrm{C}$ \\
\hline
\end{tabular}

\subsection{Thermal Management Protocol}

Thermal management charging protocol depends on the control of the ambient and cell (battery) temperatures during the charging process. Due to battery temperature being considered a key degradation metric, a new fast-charging constant temperature constant voltage (CT-CV) protocol was presented in [68] and is represented in Figure 5. The CT$\mathrm{CV}$ protocol is based on applying an initial current until $2 \mathrm{C}$ of the battery is reached, then an exponentially decaying current profile until $1 \mathrm{C}$; once the battery voltage reaches $4.2 \mathrm{~V}$, the current starts decaying until 0.1 C, as shown in Figure 5. To maintain a constant 
temperature, the Proportional-Integral-Derivative (PID) conventional controller is utilized with the aid of a feed-forward term.

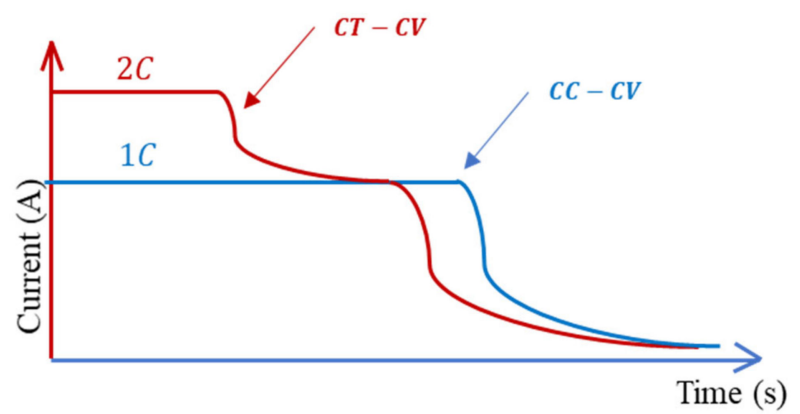

Figure 5. Schematic diagram of the Constant Temperature Constant Voltage (CT-CV) Protocol.

In [69], Pontryagin's Minimum Principle (PMP) was implemented in fast charging to solve the optimal control framework to minimize the charging time and ohmic heat generation. In [70], a 1 RC transient equivalent circuit, power loss model, and thermal model were built. The integrated fitness function was formulated to minimize the energy loss and temperature increment during the charging process where the parameters were estimated by a genetic algorithm (GA).

In [71], a two-stage constant current (2SCC) charging protocol without constant voltage (CV) charge was introduced. The 2SCC is based on applying different levels of currents and combinations to a pseudo-two-dimensional (P2D) electro-chemical-thermal coupled model. The proposed protocol studied the thermal behaviour and energy efficiency of a lithium-ion battery for a $30 \mathrm{~min}$ charging with $80 \%$ rated capacity.

To limit the degradation of the battery, it is recommended in [56] to limit the temperature to a maximum of $50{ }^{\circ} \mathrm{C}$, the surface temperature should not rise more than $15{ }^{\circ} \mathrm{C}$, and the current charging level should not exceed $3 \mathrm{C}$ capacity of the battery.

Ultrafast charging is proposed for $209 \mathrm{Wh} / \mathrm{kg}$ pouch cells lithium-ion battery in [72] using the asymmetric temperature modulation (ATM) method. The battery is charged with an initial $5 \%$ SOC to $88 \%$ SOC within almost 5 min, retaining $97.7 \%$ capacity after 1000 cycles. In addition, the ATM method prevents lithium plating within the range of $30-90 \%$ SOC and slows down capacity fade by raising the usable capacity by $10 \%$.

The aging behaviour of cycled Li-ion batteries within a wide temperature range $-20{ }^{\circ} \mathrm{C}$ to $70{ }^{\circ} \mathrm{C}$ was investigated in [73]. In this temperature range of $-20^{\circ} \mathrm{C}$ to $25^{\circ} \mathrm{C}$, the aging rate increases with a decrease in temperature from its nominal value. In the other range of $25^{\circ} \mathrm{C}$ to $70^{\circ} \mathrm{C}$, the aging rate increases with an increase in temperature from its nominal operable value. The influence of low ambient temperatures on lithium-ion battery performance was examined in $[74,75]$, where a drop in activity and amount of useable active material, as well as an increase in resistance, resulted in a decrease in the operating voltage and energy supplied.

The articles that used thermal management protocol are summarized with the MSCC protocol from the perspective of the charging time, energy consumption, charging efficiency performance, maximum applied current, cycling, and temperature rise, as shown in Table 2.

It is concluded that temperature is one of the main critical barriers in the fast-charging process, wherein Li-ion batteries are strongly impacted by the temperature change. The acceptable temperature range of thermal management, performance, and safety of the li-ion batteries is from $20^{\circ} \mathrm{C}$ to $60^{\circ} \mathrm{C}$ [76]. Battery Kinetics is sluggish at low temperatures, while aging accelerates at high temperatures [77]. Charging at low ambient temperatures leads to lithium plating $[78,79]$. Therefore, enhancing the cold-climate charging ability by pre-heating the batteries is recommended, as demonstrated in [77]. In addition, a multilayer nickel foil is embedded into the battery and used as a heater and sensor where the SOC reaches $80 \%$ within $15 \mathrm{~min}$ at $-50{ }^{\circ} \mathrm{C}$, with the preheating process derived from the 9.5 Ah pouch cell, from $-50{ }^{\circ} \mathrm{C}$ to room temperature, $25^{\circ} \mathrm{C}$, within $1 \mathrm{~min}$. In contrast, 
high temperatures accelerate the side reactions and electrode degradation [80]. Hence, the thermal-management system is mandatory during charging, otherwise the battery could reach abuse conditions and trigger an uncontrollable release of heat due to exothermic reactions and catastrophic hazards [81,82].

\subsection{Pulse Charging Current (PCC) Protocol}

As an alternative to the CC-CV and MSCC protocols, periodically changed current protocols, which are called pulse charging current (PCC) protocols, have been utilized in the charging process of lithium-ion batteries. PCC depends on the control parameters of duty cycle, frequency, and peak amplitude of the charging current pulses. PCC is implemented on the charging process of the lithium-ion to speed up the charging rate, heating the battery at low-temperature conditions, and inhibiting the growth of lithium dendrites [52]. The reason is to eliminate concentration polarization, increase the power transfer rate, and remove the constant voltage mode [83].

PCC can be categorized as a positive pulsed charging current protocol (PPCC), negative pulsed charging current protocol (NPCC), or a Bidirectional Pulsed Charging Current Protocol (BPCC), as described in Figure 6.

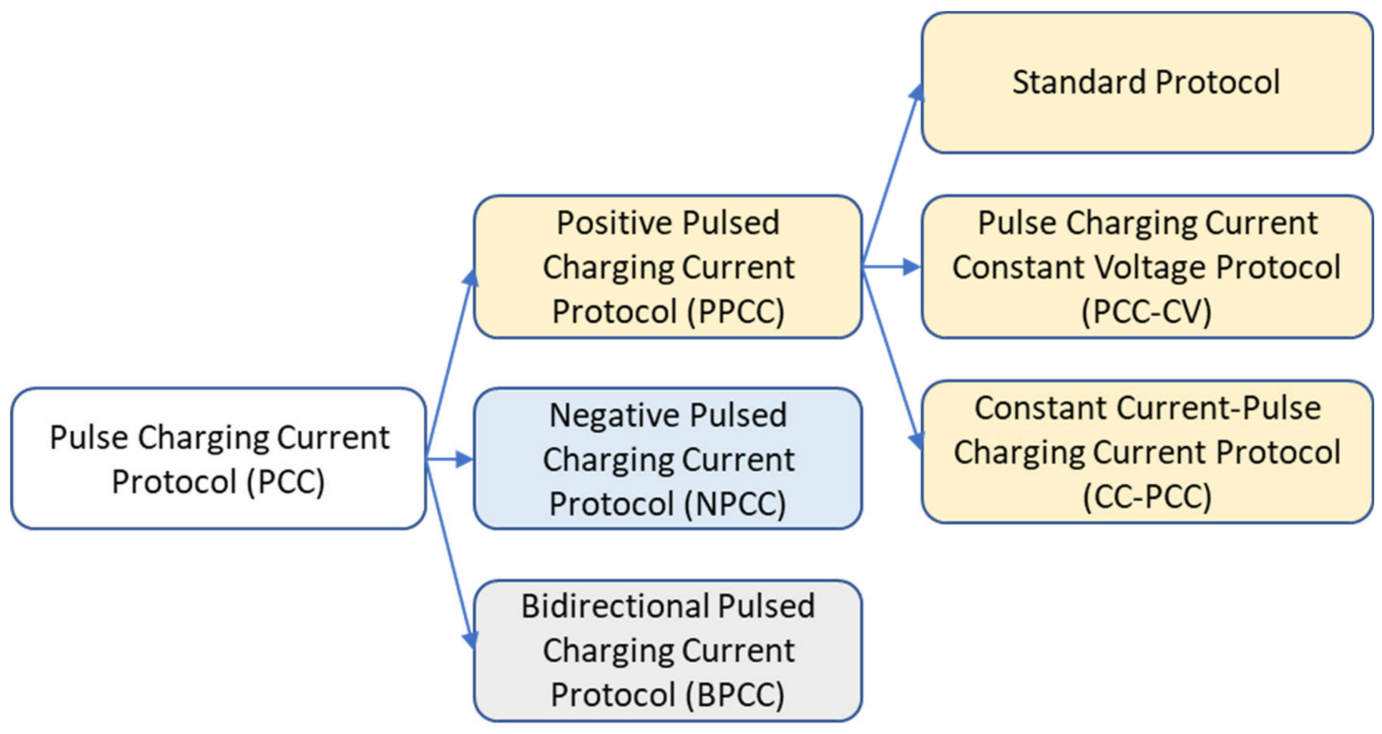

Figure 6. Overall schematic diagram of the Pulse Charging Current (PCC) Protocol.

In the next subsection, we can firstly discuss the positive pulsed charging current protocol (PPCC) and all its branches.

\subsubsection{The Positive Pulsed Charging Current (PPCC) Protocol}

\section{- $\quad$ Standard PCC Protocol}

The standard PCC protocol depends on the charging current pulses, and alternates with high and low current values, frequency, and duty cycle. The impact of charging using this protocol is a reduction in the diffusion resistance, better active material utilization, improved cycle life, and reduced charging time as the constant voltage phase becomes redundant $[83,84]$. Standard PCC is categorized into constant rest periods with constant amplitude current pulses, where $\mathrm{I}_{\text {Low }}=0 \mathrm{~A}$, as expressed in Figure 7a, with constant current pulses with different rest periods as in Figure $7 \mathrm{~b}$, decaying current pulses with constant rest periods as in Figure 7c, current pulses consisting of two different charge steps varies between predetermined currents $\mathrm{I}_{\mathrm{High}}$ and $\mathrm{I}_{\text {Low }}$ as in Figure $7 \mathrm{~d}$, and different pulse charge voltages $[84,85]$ as shown in Figure 7e. The mentioned methodologies of the standard PCC protocol allow the lithium surface concentration to reach high levels early in the charging cycle [84]. 
It is stated that the capacity and power density decrease simultaneously while energy efficiency drops as overpotential increases [85]. Consequently, the decrease in the capacity of the cell leads to performance degradation. In [53], the performance of the lithiumion battery was investigated throughout various duty cycles of $20 \%, 50 \%$, and $80 \%$, at different frequencies, of $0.1 \mathrm{kHz}, 1 \mathrm{kHz}, 6 \mathrm{kHz}, 12 \mathrm{kHz}, 50 \mathrm{kHz}$, and $100 \mathrm{kHz}$. The orthogonal arrays (OA) method was used to solve the large experimental domain to find the optimal parameters combination. The remaining battery capacity after 400 full cycles (charge/discharge) at room temperature, using this methodology, is almost $81 \%$, and $75 \%$ for both the pulsed charging current and CC-CV protocols, respectively.

It is concluded that at a $50 \%$ duty cycle, a better energy efficiency is obtained and a $25 \%$ less efficiency is obtained at a 20\% duty cycle. In addition, frequencies of less than $6 \mathrm{kHz}$ and greater than $50 \mathrm{kHz}$ produced longer charge times, and energy losses were minimized especially at $12 \mathrm{kHz}$, thereby resulting in improved performance with an increase in the cycle life compared to the CC-CV protocol. Additionally, it was observed that the higher the peak current, the faster the charging time obtained, with safety circuits implemented to prevent overcharging and overvoltage conditions, and a good cooling system should be applied due to the increase in battery surface temperature.

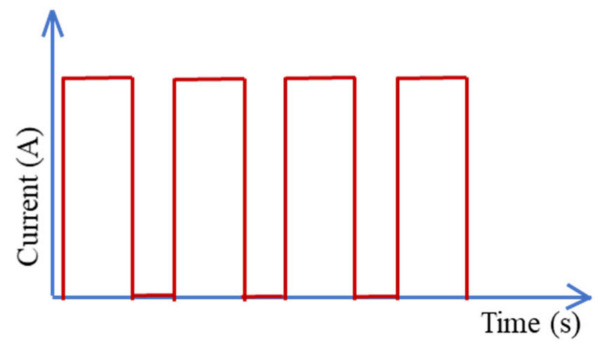

(a)

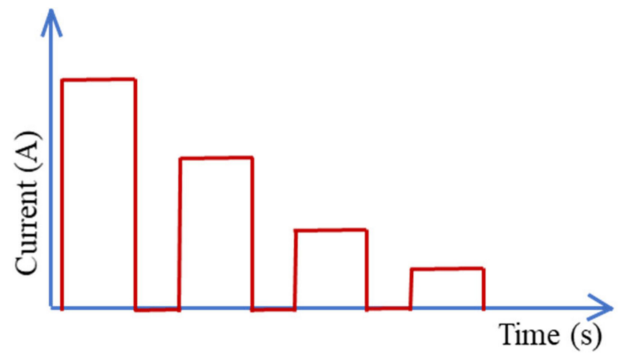

(c)

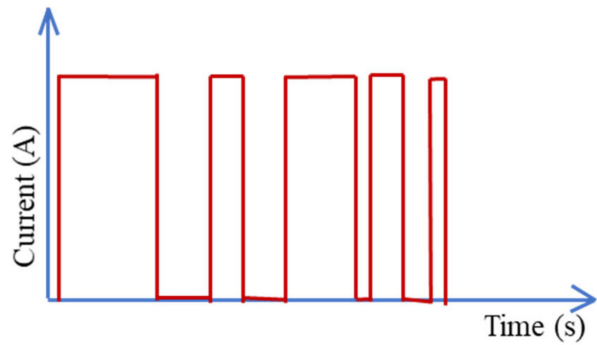

(b)

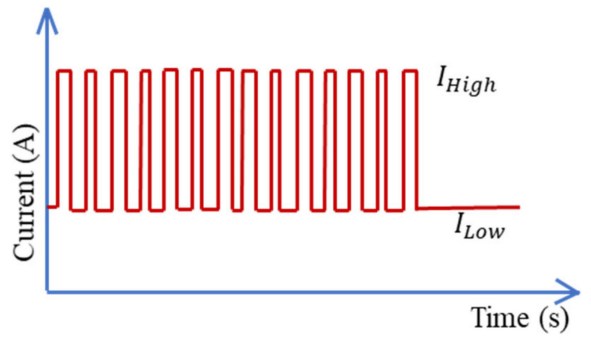

(d)

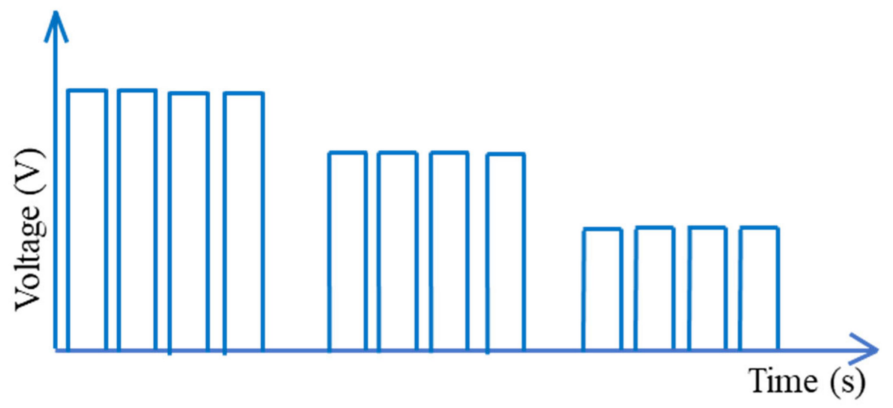

(e)

Figure 7. Types of the Standard Positive Pulsed Charging Current (PPCC) Protocol; (a) standard protocol with equal duty cycle, (b) standard protocol with various duty cycle, (c) standard protocol with decaying current, (d) standard protocol with upper and lower current limit, and (e) different pulse-charge voltages. 


\section{- Pulse Charging Current-Constant Voltage (PCC-CV) Protocol}

PCC-CV protocol depends on a sequence of pulse charging currents for a specific interval time which is followed by a constant voltage stage until full charging capacity is reached, as shown in Figure 8a. The PCC-CV was proposed in [86] to study the capacity fading and service life of lithium-ion batteries under different charging-discharging strategies, which reflects the growth of solid electrolyte interphase (SEI). Compared with the $\mathrm{CC}-\mathrm{CV}$ protocol, the PCC-CV revealed better cyclic performances because of the smaller average currents.

\section{- Constant Current-Pulse Charging Current (CC-PCC) Protocol}

In this protocol, the lithium-ion battery is charged using a constant current (CC) mode until a predetermined voltage level is reached, then the CC mode is switched to pulsating charging current mode as shown in Figure 8b. In [31], the Constant Current-Pulse Charging Current (CC-PCC) protocol was proposed. Rectangular current pulses with a constant duty cycle of $50 \%$ were specified and utilized to avoid distortions due to different mean charging currents, reflected by reducing the charging current or increasing the pause lengths. However, It is concluded that the CC-PCC protocol leads to a longer charging time than the CC-CV protocol.

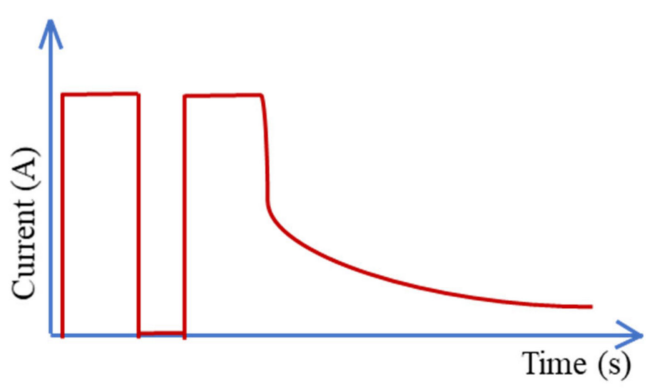

(a)

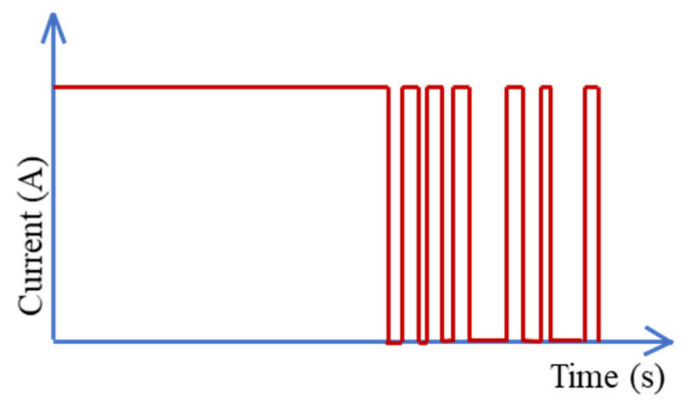

(b)

Figure 8. (a) Pulse Charging Current-Constant Voltage (PCC-CV) protocol, and (b) Constant CurrentPulse Charging Current (CC-PCC) protocol.

A comparison between the different categories of the positive pulsed charging current (PPCC) protocol is presented in Table 3. Herein, it is concluded that all the proposed methodologies of the PPCC protocol have almost the same effect on the cycle life while used in the charging process.

Table 3. Comparison between different types of Positive Pulsed Charging Current (PPCC) Protocol.

\begin{tabular}{ccccc}
\hline Protocol Type & Duty Cycle & Frequency & Compared with & Impact \\
\hline $\begin{array}{c}\text { Standard PCC based on } \\
\text { Orthogonal arrays [31] }\end{array}$ & $50 \%$ & $12 \mathrm{kHz}$ & CC-CV & +100 cycle life \\
Standard PCC [87] & $50 \%$ & $25 \mathrm{~Hz}$ & CC-CV & $\begin{array}{c}\text { Same cycle life } \\
\text { Same cycle life, only a somewhat } \\
\text { faster capacity fade can be observed }\end{array}$ \\
$\begin{array}{c}\text { Pulse charging current } \\
\text { constant voltage } \\
\text { (PCC-CV) [86] }\end{array}$ & $50 \%$ & $1 \mathrm{~Hz}$ & CC-CV & Same cycle life \\
$\begin{array}{c}\text { Constant Current-Pulse } \\
\text { Charging Current } \\
\text { (CC-PCC) [31] }\end{array}$ & $50 \%$ & $0.02 \mathrm{~Hz}$ & CC-CV & Same cycle life \\
\hline
\end{tabular}




\subsubsection{Bidirectional Pulsed Charging Current (BPCC) Protocol}

Low-temperature charging is considered a major challenge for lithium-ion batteries due to the degradation and cycle life [83]. Charging at low temperatures increases polarization, affecting capacity, causing an internal short circuit, and presenting the possibility of lithium plating. Herein, Joule heat is used to generate self-heating via the internal resistance of the battery and eliminate heat loss from any external heating equipment [83]. The PCC protocol is used to warm the battery from $-10^{\circ} \mathrm{C}$ to $3^{\circ} \mathrm{C}$ firstly, and then the charging is switched to the CC-CV protocol [83].

Furthermore, the bidirectional pulsed current is proposed to obtain the main data of the thermal action to comprehensively analyze heat-generation characteristics and the thermoelectric coupling model based on the second-order RC circuit to verify the basic principle [88]. The bidirectional pulsed current increases the heating speed, consequently decreasing the risk of lithium plating and ensuring safety. It is concluded that whenever the bidirectional pulsed current methodology is implemented, at a low temperature and a high current rate, overcharge or discharge will not significantly affect the life span or increase the safety risk of lithium-ion batteries. BPCC protocol has different implementation types as shown in Figure 9, based on the existing interval time between the positive and negative pulses [88]. Normally, the negative current helps in reducing the polarization voltage caused by the positive pulses and polarizes it in the opposite direction, as stated in [89].

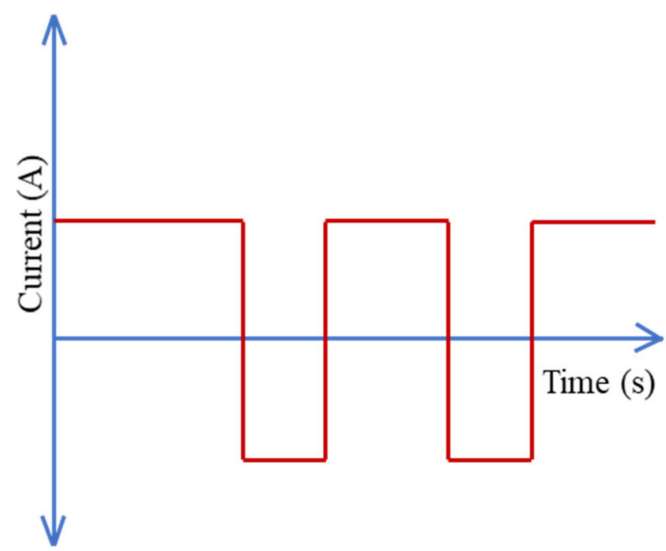

(a)

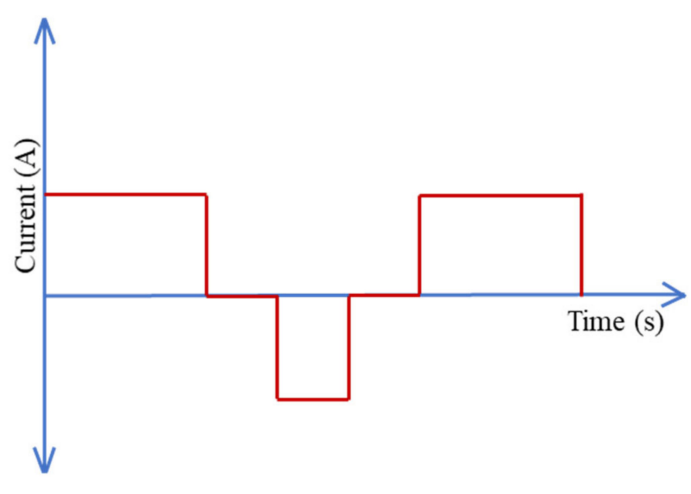

(b)

Figure 9. Different types of the ideal bidirectional pulsed charging current (BPCC) where (a) the standard normal operation, and (b) Operation while having a relaxing interval time between the positive and negative pulses.

\subsubsection{Negative Pulsed Charging Current}

The negative pulse fast charging method (FCNP) was analyzed in [90], and ensured ion recovery from metallic lithium, hence the capacity loss was minimized; however, the same charging speed as the CC charging protocol was obtained. In addition, FCNP limits side reaction during anode potential, terminal cut-off voltage, and side reaction rate by incorporating it into a reduced-order electrochemical model (ROM) with an extended Kalman filter. A full comparison between the CC-CV at different capacities and FCNP is implemented on the pouch-type lithium-ion battery cell, freshly charged and after various cycles, as expressed in Table 4 . The charging time for up to $100 \%$ SOC by FCNP is longer than that of the $3 \mathrm{C} \mathrm{CC}-\mathrm{CV}$ charging protocol, however, it becomes shorter as degradation is in progress, particularly after 40 cycles. On the other hand, the capacity loss by FCNP is comparable with that of the $2 \mathrm{C} \mathrm{CC}-\mathrm{CV}$ charging protocol, which is approximately $23 \%$ less than that of the 3C CC-CV charging protocol after 60 cycles. 
Table 4. A Comparison between the negative pulsed charging current and CC-CV protocol.

\begin{tabular}{ccccc}
\hline & $\begin{array}{c}\text { Up to } \mathbf{8 0} \% \text { SOC } \\
\text { Fresh Cell }\end{array}$ & $\begin{array}{c}\text { Up to 100\% } \\
\text { SOC Fresh Cell }\end{array}$ & $\begin{array}{c}\text { Up to } \mathbf{1 0 0 \%} \\
\text { SOC after } \\
\text { 20 Cycles }\end{array}$ & $\begin{array}{c}\text { Up to } \mathbf{1 0 0 \%} \\
\text { SOC after } \\
\mathbf{6 0} \text { Cycles }\end{array}$ \\
\hline $3 C$ CC-CV & $15.7 \mathrm{~min}$ & $44 \mathrm{~min}$ & $47.3 \mathrm{~min}$ & $55.2 \mathrm{~min}$ \\
2 C CC-CV & $22.8 \mathrm{~min}$ & $56 \mathrm{~min}$ & $56.1 \mathrm{~min}$ & $59.2 \mathrm{~min}$ \\
FCNP & $16.6 \mathrm{~min}$ & $49 \mathrm{~min}$ & $51.1 \mathrm{~min}$ & $52 \mathrm{~min}$ \\
\hline
\end{tabular}

The Pulse Charging Current Protocol, with all its proposed categories, reduces the risk of lithium plating, reduces the charging time, increases charging efficiency and battery lifespan [91], leads to low heating and the low degradation of materials [15]. In addition, the risk arising from charging batteries at low temperatures can be alleviated using this protocol. However, the main drawback is the complexity of the controller.

We can summarize the previous findings and the current challenges of the power management protocol with all its methodologies by stating their advantages and disadvantages, which are as presented in Figure 10.

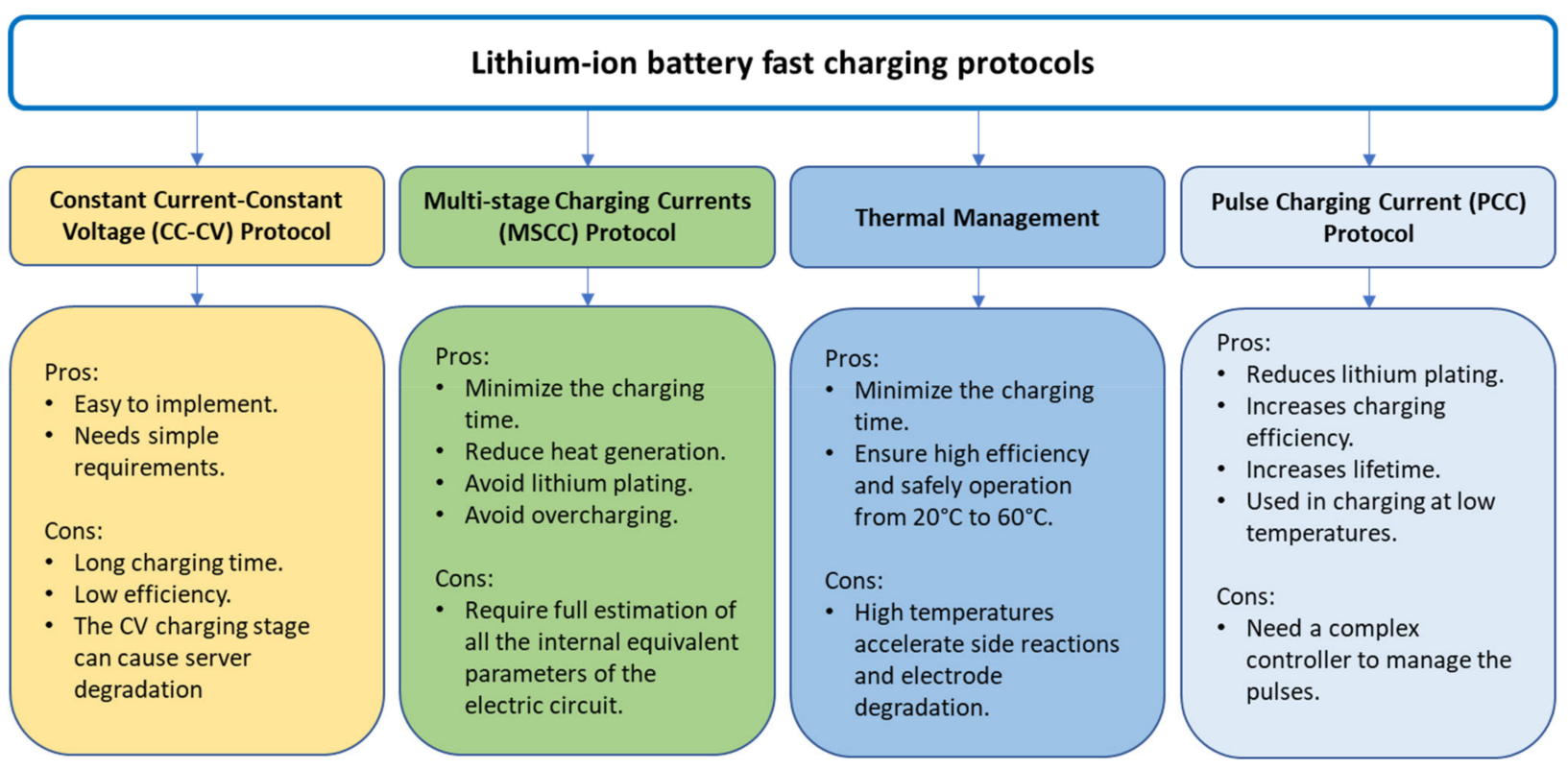

Figure 10. The pros and cons of the power management protocol with all its categories.

\section{Material Aspects Charging Protocol}

Recently, researchers have directed their attention to the Extreme Fast Charging (XFC) which mandates a charging rate equal to or greater than 6 C [92]. XFC leads to cathode particle cracking, low active material utilization, electrolyte-electrode side reactions, and lithium plating at the anode. The mentioned cons can be summarized as electrode variability $[92,93]$.

In [92], the cathode particle cracking and electrolyte modification (concentrated electrolyte and low viscosity additives) limitations have been identified to ensure safety and stability problems. In [94], an electrolyte additive trimethylsilyl isothiocyanate (TMSNCS), based on amino silane with a high electron-donating ability that can scavenge $\mathrm{HF}$ and $\mathrm{PF}_{5}$ has been proposed to solve the detrimental effects of $\mathrm{LiPF}_{6}$.

The authors in [95] investigated the XFC performance for a cell with a low loading of $1.5 \mathrm{mAh} . \mathrm{cm}^{-2}$ and moderate loading of $2.5 \mathrm{mAh} . \mathrm{cm}^{-2}$. It is concluded that the combination of increasing the battery temperature, reduction in the electrode tortuosity, and enhancement of the ion transport in the electrolyte are required to facilitate the CFC for high-energy lithium-ion batteries. Lithium bis (fluor sulfonyl) imide (LFDI) was utilized 
in [96] to provide a fast charging capability of high energy density because of its high conductivity and high lithium-ion transference number compared to $\mathrm{LiPF}_{6}$ salt. In addition, a physical-chemical model is introduced in [97], which improved the discharge-rate capability of the lithium-ion cells via the laser-structured graphite anodes.

Fast charging protocols based on the material modification are interesting and require a detailed and clear description as well as a comparison between different physical, material aspects, and chemical structures of the lithium-ion batteries to evaluate and summarize the extremely fast charging protocol, such as that mentioned in the review papers $[92,93,98,99]$.

\section{Conclusions}

This paper reviews the current up-to-date status and implementation of the lithiumion battery fast charging protocols. The fast-charging protocols are divided into power and thermal management protocols, which depend on the electrical charging current, voltage, and cell temperature. Power and thermal management protocols are categorized as constant current constant voltage (CC-CV), multi-stage charging current (MSCC), thermal management, and pulse charging current protocols. In addition, fast charging protocols based on material modification, physics, structures, and aspects were reviewed. This paper reveals the full comparison between the sub charging methods of each charging protocol and the impact on the charging time, efficiency, lifetime, cell temperature, and energy loss of the lithium-ion batteries. In addition, we presented up-to-date charging strategies that are not mentioned in other literature reviews and stated the pros and cons of each charging protocol to improve the existing protocols and initiate novel research. Importantly, there is a direct need to enhance the charging process at different temperatures and at a relative humidity for applicability worldwide and during different seasons. Therefore, artificial intelligence (AI) has to be applied in proposing a dynamic charging protocol and improving the modelling of the lithium-ion battery at various ambient circumstances to ensure a safe charging process with a minimal charging current, maximum efficiency, and increased lifespan.

Author Contributions: Conceptualization, methodology, investigation, writing - original draft preparation, visualization, P.M.; Supervision, project administration, analysis, writing-review and editing, H.A.G.; Supervision, project administration, analysis, writing-review and editing, S.M. All authors have read and agreed to the published version of the manuscript.

Funding: This research received no external funding.

Institutional Review Board Statement: Not applicable.

Informed Consent Statement: Not applicable.

Data Availability Statement: The data has been extracted from the references stated below in the Reference section.

Acknowledgments: This work was supported by the Centre for Emerging Learning Technology (CELT) at The British University in Egypt (BUE), the Electrical Engineering department, Faculty of Engineering at The British University in Egypt (BUE), and the Division of Electrical and Electronic Engineering, London South Bank University (LSBU).

Conflicts of Interest: The authors declare that they have no known competing financial interests or personal relationships that could have appeared to influence the work reported in this paper.

\section{References}

1. Sanguesa, J.; Torres-Sanz, V.; Garrido, P.; Martinez, F.; Marquez-Barja, J. A Review on Electric Vehicles: Technologies and Challenges. Smart Cities 2021, 4, 22. [CrossRef]

2. Khaksari, A.; Tsaousoglou, G.; Makris, P.; Steriotis, K.; Efthymiopoulos, N.; Varvarigos, E. Sizing of electric vehicle charging stations with smart charging capabilities and quality of service requirements. Sustain. Cities Soc. 2021, 70, 102872. [CrossRef]

3. International Energy Agency (IEA). Global EV Outlook 2021, Accelerating Ambitions Despite the Pandemic. April 2021. Available online: https:/ /www.iea.org/reports/global-ev-outlook-2021 (accessed on 30 October 2021). 
4. Yilmaz, M.; Krein, P.T. Review of Battery Charger Topologies, Charging Power Levels, and Infrastructure for Plug-In Electric and Hybrid Vehicles. IEEE Trans. Power Electron. 2013, 28, 2151-2169. [CrossRef]

5. $\quad$ El-Bayeh, C.Z.; Alzaareer, K.; Aldaoudeyeh, A.-M.I.; Brahmi, B.; Zellagui, M. Charging and Discharging Strategies of Electric Vehicles: A Survey. World Electr. Veh. J. 2021, 12, 11. [CrossRef]

6. Khalid, M.R.; Alam, M.S.; Sarwar, A.; Asghar, M.J. A Comprehensive review on electric vehicles charging infrastructures and their impacts on power-quality of the utility grid. eTransportation 2019, 1, 100006. [CrossRef]

7. Muthukumar, M.; Rengarajan, N.; Velliyangiri, B.; Omprakas, M.; Rohit, C.; Raja, U.K. The development of fuel cell electric vehicles-A review. Mater. Today: Proc. 2021, 45, 1181-1187. [CrossRef]

8. Nour, M.; Chaves-Ávila, J.P.; Magdy, G.; Sánchez-Miralles, Á. Review of positive and negative impacts of electric vehicles charging on electric power systems. Energies 2020, 13, 4675. [CrossRef]

9. Chen, T.; Zhang, X.-P.; Wang, J.; Li, J.; Wu, C.; Hu, M.; Bian, H. A Review on Electric Vehicle Charging Infrastructure Development in the UK. J. Mod. Power Syst. Clean Energy 2020, 8, 193-205. [CrossRef]

10. Guarnieri, M. Looking back to electric cars. In Proceedings of the 2012 Third IEEE HISTory of ELectro-technology Conference (HISTELCON), Pavia, Italy, 5-7 September 2012; pp. 1-6.

11. IEC 62196-1:2014; Plugs, Socket-Outlets, Vehicle Couplers and Vehicle Inlets-Conductive Charging of Electric Vehicles-Part 1 International Electrotechnical Commission (IEC): Geneva, Switzerland, 2014.

12. J1772_201710; SAE Electric Vehicle and Plug in Hybrid Electric Vehicle Conductive Charge Couplerl. SAE International: Warrendale, PA, USA, 2017.

13. Shareef, H.; Islam, M.M.; Mohamed, A. A review of the stage-of-the-art charging technologies, placement methodologies, and impacts of electric vehicles. Renew. Sustain. Energy Rev. 2016, 64, 403-420. [CrossRef]

14. Das, H.S.; Rahman, M.M.; Li, S.; Tan, C.W. Electric vehicles standards, charging infrastructure, and impact on grid integration: A technological review. Renew. Sustain. Energy Rev. 2020, 120, 109618. [CrossRef]

15. Duru, K.K.; Karra, C.; Venkatachalam, P.; Betha, S.A.; Madhavan, A.A.; Kalluri, S. Critical Insights into Fast Charging Techniques for Lithium-Ion Batteries in Electric Vehicles. IEEE Trans. Device Mater. Reliab. 2021, 21, 137-152. [CrossRef]

16. Ucer, E.; Koyuncu, I.; Kisacikoglu, M.C.; Yavuz, M.; Meintz, A.; Rames, C. Modeling and Analysis of a Fast Charging Station and Evaluation of Service Quality for Electric Vehicles. IEEE Trans. Transp. Electrif. 2019, 5, 215-225. [CrossRef]

17. Tu, H.; Feng, H.; Srdic, S.; Lukic, S. Extreme Fast Charging of Electric Vehicles: A Technology Overview. IEEE Trans. Transp. Electrif. 2019, 5, 861-878. [CrossRef]

18. Yang, Y.; El Baghdadi, M.; Lan, Y.; Benomar, Y.; Van Mierlo, J.; Hegazy, O. Design Methodology, Modeling, and Comparative Study of Wireless Power Transfer Systems for Electric Vehicles. Energies 2018, 11, 1716. [CrossRef]

19. Mohamed, N.; Aymen, F.; Alqarni, M.; Turky, R.A.; Alamri, B.; Ali, Z.M.; Aleem, S.H.A. A new wireless charging system for electric vehicles using two receiver coils. Ain Shams Eng. J. 2021, 13, 101569. [CrossRef]

20. $\mathrm{Wu}, \mathrm{H}$. A Survey of Battery Swapping Stations for Electric Vehicles: Operation Modes and Decision Scenarios. IEEE Trans. Intell. Transp. Syst. 2021, 1-23. [CrossRef]

21. Sarker, M.R.; Pandžić, H.; Ortega-Vazquez, M.A. Optimal operation and services scheduling for an electric vehicle battery swapping station. IEEE Trans. Power Syst. 2014, 30, 901-910. [CrossRef]

22. The Massachusetts Department of Energy Resources. Installation Guide for Electric Vehicle Supply Equipment (EVSE). June 2014. Available online: https://www.mass.gov/doc/electric-vehicle-charging-infrastructure-manual/download (accessed on 30 October 2021).

23. Knez, M.; Zevnik, G.K.; Obrecht, M. A review of available chargers for electric vehicles: United States of America, European Union, and Asia. Renew. Sustain. Energy Rev. 2019, 109, 284-293. [CrossRef]

24. Wassiliadis, N.; Schneider, J.; Frank, A.; Wildfeuer, L.; Lin, X.; Jossen, A.; Lienkamp, M. Review of fast charging strategies for lithium-ion battery systems and their applicability for battery electric vehicles. J. Energy Storage 2021, 44, 103306. [CrossRef]

25. Gao, Y.; Zhang, X.; Cheng, Q.; Guo, B.; Yang, J. Classification and Review of the Charging Strategies for Commercial Lithium-Ion Batteries. IEEE Access 2019, 7, 43511-43524. [CrossRef]

26. Chen, C.; Wei, Z.; Knoll, A.C. Charging Optimization for Li-ion Battery in Electric Vehicles: A Review. IEEE Trans. Transp. Electrif. 2021, 1-23. [CrossRef]

27. Miao, Y.; Hynan, P.; Von Jouanne, A.; Yokochi, A. Current Li-Ion Battery Technologies in Electric Vehicles and Opportunities for Advancements. Energies 2019, 12, 1074. [CrossRef]

28. Chen, S.; Bao, N.; Garg, A.; Peng, X.; Gao, L. A Fast Charging-Cooling Coupled Scheduling Method for a Liquid Cooling-Based Thermal Management System for Lithium-Ion Batteries. Engineering 2021, 7, 1165-1176. [CrossRef]

29. Ding, Y.; Cano, Z.P.; Yu, A.; Lu, J.; Chen, Z. Automotive Li-Ion Batteries: Current Status and Future Perspectives. Electrochem. Energy Rev. 2019, 2, 1-28. [CrossRef]

30. Guo, Z.; Liaw, B.Y.; Qiu, X.; Gao, L.; Zhang, C. Optimal charging method for lithium ion batteries using a universal voltage protocol accommodating aging. J. Power Sources 2015, 274, 957-964. [CrossRef]

31. Keil, P.; Jossen, A. Charging protocols for lithium-ion batteries and their impact on cycle life-An experimental study with different 18650 high-power cells. J. Energy Storage 2016, 6, 125-141. [CrossRef]

32. Sachan, S.; Deb, S.; Singh, S.N. Different charging infrastructures along with smart charging strategies for electric vehicles. Sustain. Cities Soc. 2020, 60, 102238. [CrossRef] 
33. Tamilselvi, S.; Gunasundari, S.; Karuppiah, N.; Rk, A.R.; Madhusudan, S.; Nagarajan, V.M.; Sathish, T.; Shamim, M.Z.M.; Saleel, C.A.; Afzal, A. A Review on Battery Modelling Techniques. Sustainability 2021, 13, 10042. [CrossRef]

34. Makeen, P.; Ghali, H.A.; Memon, S. Experimental and Theoretical Analysis of the Fast Charging Polymer Lithium-Ion Battery Based on Cuckoo Optimization Algorithm (COA). IEEE Access 2020, 8, 140486-140496. [CrossRef]

35. Khalfi, J.; Boumaaz, N.; Soulmani, A.; Laadissi, E.M. Nonlinear Modeling of Lithium-Ion Battery Cells for Electric Vehicles using a Hammerstein-Wiener Model. J. Electr. Eng. Technol. 2021, 16, 659-669. [CrossRef]

36. Seaman, A.; Dao, T.-S.; McPhee, J. A survey of mathematics-based equivalent-circuit and electrochemical battery models for hybrid and electric vehicle simulation. J. Power Sources 2014, 256, 410-423. [CrossRef]

37. Li, S.; Li, J.; He, H.; Wang, H. Lithium-ion battery modeling based on Big Data. Energy Procedia 2019, 159, 168-173. [CrossRef]

38. Mehta, R.; Gupta, A. An improved single-particle model with electrolyte dynamics for high current applications of lithium-ion cells. Electrochim. Acta 2021, 389, 138623. [CrossRef]

39. Tian, J.; Wang, Y.; Chen, Z. An improved single particle model for lithium-ion batteries based on main stress factor compensation. J. Clean. Prod. 2021, 278, 123456. [CrossRef]

40. An, F.; Zhou, W.; Li, P. A comparison of model prediction from P2D and particle packing with experiment. Electrochim. Acta 2021, 370, 137775. [CrossRef]

41. Bermejo, R. Numerical analysis of a finite element formulation of the P2D model for Lithium-ion cells. Numer. Math. 2021, 149, 463-505. [CrossRef]

42. Zhou, F.; Bao, C. Analysis of the lithium-ion battery capacity degradation behavior with a comprehensive mathematical model. $J$. Power Sources 2021, 515, 230630. [CrossRef]

43. Shuai, W.; Li, E.; Wang, H. An equivalent circuit model of a deformed Li-ion battery with parameter identification. Int. J. Energy Res. 2020, 44, 8372-8387. [CrossRef]

44. Zhang, X.; Zhang, W.; Lei, G. A Review of Li-ion Battery Equivalent Circuit Models. Trans. Electr. Electron. Mater. 2016, 17, 311-316. [CrossRef]

45. Grandjean, T.R.B.; McGordon, A.; Jennings, P.A. Structural Identifiability of Equivalent Circuit Models for Li-Ion Batteries Energies 2017, 10, 90. [CrossRef]

46. Vetter, J.; Novák, P.; Wagner, M.R.; Veit, C.; Möller, K.-C.; Besenhard, J.O.; Winter, M.; Wohlfahrt-Mehrens, M.; Vogler, C.; Hammouche, A. Ageing mechanisms in lithium-ion batteries. J. Power Sources 2005, 147, 269-281. [CrossRef]

47. Lee, J.H.; Lee, H.M.; Ahn, S. Battery dimensional changes occurring during charge/discharge cycles-Thin rectangular lithium ion and polymer cells. J. Power Sources 2003, 119-121, 833-837. [CrossRef]

48. Cho, I.-H.; Lee, P.-Y.; Kim, J.-H. Analysis of the Effect of the Variable Charging Current Control Method on Cycle Life of Li-ion Batteries. Energies 2019, 12, 3023. [CrossRef]

49. Wu, C.; Zhu, C.; Ge, Y.; Zhao, Y. A Review on Fault Mechanism and Diagnosis Approach for Li-Ion Batteries. J. Nanomater. 2015, 2015, 8. [CrossRef]

50. Belov, D.; Yang, M.-H. Failure mechanism of Li-ion battery at overcharge conditions. J. Solid State Electrochem. 2008, 12, 885-894. [CrossRef]

51. Makeen, P.; Memon, S.; Elkasrawy, M.A.; Abdullatif, S.O.; Ghali, H.A. Smart green charging scheme of centralized electric vehicle stations. Int. J. Green Energy 2021, 1-9. [CrossRef]

52. Zhu, S.; Hu, C.; Xu, Y.; Jin, Y.; Shui, J. Performance improvement of lithium-ion battery by pulse current. J. Energy Chem. 2020, 46, 208-214. [CrossRef]

53. Amanor-Boadu, J.M.; Guiseppi-Elie, A. Improved Performance of Li-ion Polymer Batteries through Improved Pulse Charging Algorithm. Appl. Sci. 2020, 10, 895. [CrossRef]

54. Chu, Z.; Feng, X.; Lu, L.; Li, J.; Han, X.; Ouyang, M. Non-destructive fast charging algorithm of lithium-ion batteries based on the control-oriented electrochemical model. Appl. Energy 2017, 204, 1240-1250. [CrossRef]

55. Notten, P.; Veld, J.O.H.; van Beek, J. Boostcharging Li-ion batteries: A challenging new charging concept. J. Power Sources 2005, 145, 89-94. [CrossRef]

56. Mathieu, R.; Briat, O.; Gyan, P.; Vinassa, J.-M. Fast charging for electric vehicles applications: Numerical optimization of a multi-stage charging protocol for lithium-ion battery and impact on cycle life. J. Energy Storage 2021, 40, 102756. [CrossRef]

57. Chen, G.-J.; Liu, Y.-H.; Wang, S.-C.; Luo, Y.-F.; Yang, Z.-Z. Searching for the optimal current pattern based on grey wolf optimizer and equivalent circuit model of Li-ion batteries. J. Energy Storage 2021, 33, 101933. [CrossRef]

58. Li, Y.; Li, K.; Xie, Y.; Liu, J.; Fu, C.; Liu, B. Optimized charging of lithium-ion battery for electric vehicles: Adaptive multistage constant current-constant voltage charging strategy. Renew. Energy 2020, 146, 2688-2699. [CrossRef]

59. Hu, X.; Zheng, Y.; Lin, X.; Xie, Y. Optimal Multistage Charging of NCA/Graphite Lithium-Ion Batteries Based on ElectrothermalAging Dynamics. IEEE Trans. Transp. Electrif. 2020, 6, 427-438. [CrossRef]

60. Jiang, L.; Li, Y.; Huang, Y.; Yu, J.; Qiao, X.; Wang, Y.; Huang, C.; Cao, Y. Optimization of multi-stage constant current charging pattern based on Taguchi method for Li-Ion battery. Appl. Energy 2020, 259, 114148. [CrossRef]

61. Lee, C.-H.; Chang, T.-W.; Hsu, S.-H.; Jiang, J.-A. Taguchi-based PSO for searching an optimal four-stage charge pattern of Li-ion batteries. J. Energy Storage 2019, 21, 301-309. [CrossRef]

62. Sun, J.; Ma, Q.; Liu, R.; Wang, T.; Tang, C. A novel multiobjective charging optimization method of power lithium-ion batteries based on charging time and temperature rise. Int. J. Energy Res. 2019, 43, 7672-7681. [CrossRef] 
63. Makeen, P.; Ghali, H.; Memon, S. Controllable Electric Vehicle Fast Charging Approach Based on Multi-Stage Charging Current Methodology. In Proceedings of the 2020 IEEE International Conference on Power and Energy (PECon), Online, 7-8 December 2020; pp. 398-403.

64. Yun, S.-S.; Kee, S.-C. Improved Multilevel Multistage Constant-Current Constant-Voltage Superfast Charging of Multiple Cells. J. Electr. Eng. Technol. 2021, 17, 209-219. [CrossRef]

65. Jeon, S.U.; Park, J.-W.; Kang, B.-K.; Lee, H.-J. Study on Battery Charging Strategy of Electric Vehicles Considering Battery Capacity. IEEE Access 2021, 9, 89757-89767. [CrossRef]

66. Tomaszewska, A.; Chu, Z.; Feng, X.; O’Kane, S.; Liu, X.; Chen, J.; Ji, C.; Endler, E.; Li, R.; Liu, L.; et al. Lithium-ion battery fast charging: A review. eTransportation 2019, 1, 100011. [CrossRef]

67. Min, H.; Sun, W.; Li, X.; Guo, D.; Yu, Y.; Zhu, T.; Zhao, Z. Research on the Optimal Charging Strategy for Li-Ion Batteries Based on Multi-Objective Optimization. Energies 2017, 10, 709. [CrossRef]

68. Patnaik, L.; Praneeth, A.V.J.S.; Williamson, S.S. A Closed-Loop Constant-Temperature Constant-Voltage Charging Technique to Reduce Charge Time of Lithium-Ion Batteries. IEEE Trans. Ind. Electron. 2019, 66, 1059-1067. [CrossRef]

69. Nambisan, P.; Saha, P.; Khanra, M. Real-time optimal fast charging of Li-ion batteries with varying temperature and charging behaviour constraints. J. Energy Storage 2021, 41, 102918. [CrossRef]

70. Chen, Z.; Shu, X.; Xiao, R.; Yan, W.; Liu, Y.; Shen, J. Optimal charging strategy design for lithium-ion batteries considering minimization of temperature rise and energy loss. Int. J. Energy Res. 2019, 43, 4344-4358. [CrossRef]

71. Xu, M.; Wang, R.; Reichman, B.; Wang, X. Modeling the effect of two-stage fast charging protocol on thermal behavior and charging energy efficiency of lithium-ion batteries. J. Energy Storage 2018, 20, 298-309. [CrossRef]

72. Liu, T.; Yang, X.-G.; Ge, S.; Leng, Y.; Wang, C.-Y. Ultrafast charging of energy-dense lithium-ion batteries for urban air mobility. eTransportation 2021, 7, 100103. [CrossRef]

73. Waldmann, T.; Wilka, M.; Kasper, M.; Fleischhammer, M.; Wohlfahrt-Mehrens, M. Temperature dependent ageing mechanisms in Lithium-ion batteries-A Post-Mortem study. J. Power Sources 2014, 262, 129-135. [CrossRef]

74. Wu, H.; Zhang, X.; Cao, R.; Yang, C. An investigation on electrical and thermal characteristics of cylindrical lithium-ion batteries at low temperatures. Energy 2021, 225, 120223. [CrossRef]

75. Jaguemont, J.; Boulon, L.; Dubé, Y. Characterization and Modeling of a Hybrid-Electric-Vehicle Lithium-Ion Battery Pack at Low Temperatures. IEEE Trans. Veh. Technol. 2016, 65, 1-14. [CrossRef]

76. Rodrigues, M.-T.F.; Babu, G.; Gullapalli, H.; Kalaga, K.; Sayed, F.N.; Kato, K.; Joyner, J.; Ajayan, P.M. A materials perspective on Li-ion batteries at extreme temperatures. Nat. Energy 2017, 2, 17108. [CrossRef]

77. Liu, Y.; Zhu, Y.; Cui, Y. Challenges and opportunities towards fast-charging battery materials. Nat. Energy 2019, 4, 540-550. [CrossRef]

78. Yang, X.-G.; Zhang, G.; Ge, S.; Wang, C.-Y. Fast charging of lithium-ion batteries at all temperatures. Proc. Natl. Acad. Sci. USA 2018, 115, 7266-7271. [CrossRef]

79. Li, Z.; Huang, J.; Liaw, B.Y.; Metzler, V.; Zhang, J. A review of lithium deposition in lithium-ion and lithium metal secondary batteries. J. Power Sources 2014, 254, 168-182. [CrossRef]

80. Leng, F.; Tan, C.M.; Pecht, M. Effect of Temperature on the Aging rate of Li Ion Battery Operating above Room Temperature. Sci. Rep. 2015, 5, 12967. [CrossRef]

81. Bandhauer, T.M.; Garimella, S.; Fuller, T.F. A Critical Review of Thermal Issues in Lithium-Ion Batteries. J. Electrochem. Soc. 2011, 158, R1. [CrossRef]

82. Liu, K.; Liu, Y.; Lin, D.; Pei, A.; Cui, Y. Materials for lithium-ion battery safety. Sci. Adv. 2018, 4, eaas9820. [CrossRef]

83. Li, J.; Murphy, E.; Winnick, J.; Kohl, P.A. The effects of pulse charging on cycling characteristics of commercial lithium-ion batteries. J. Power Sources 2001, 102, 302-309. [CrossRef]

84. Purushothaman, B.; Landau, U. Rapid charging of lithium-ion batteries using pulsed currents: A theoretical analysis. J. Electrochem. Soc. 2006, 153, A533. [CrossRef]

85. Li, S.; Wu, Q.; Zhang, D.; Liu, Z.; He, Y.; Wang, Z.L.; Sun, C. Effects of pulse charging on the performances of lithium-ion batteries. Nano Energy 2019, 56, 555-562. [CrossRef]

86. Lv, H.; Huang, X.; Liu, Y. Analysis on pulse charging-Discharging strategies for improving capacity retention rates of lithium-ion batteries. Ionics 2020, 26, 1749-1770. [CrossRef]

87. Amanor-Boadu, J.M.; Guiseppi-Elie, A.; Sánchez-Sinencio, E. The impact of pulse charging parameters on the life cycle of lithium-ion polymer batteries. Energies 2018, 11, 2162. [CrossRef]

88. Qin, Y.; Du, J.; Lu, L.; Gao, M.; Haase, F.; Li, J.; Ouyang, M. A rapid lithium-ion battery heating method based on bidirectional pulsed current: Heating effect and impact on battery life. Appl. Energy 2020, 280, 115957. [CrossRef]

89. Qiu, C.; He, G.; Shi, W.; Zou, M.; Liu, C. The polarization characteristics of lithium-ion batteries under cyclic charge and discharge. J. Solid State Electrochem. 2019, 23, 1887-1902. [CrossRef]

90. Song, M.; Choe, S.-Y. Fast and safe charging method suppressing side reaction and lithium deposition reaction in lithium ion battery. J. Power Sources 2019, 436, 226835. [CrossRef]

91. Zhao, Y.; Lu, B.; Song, Y.; Zhang, J. A modified pulse charging method for lithium-ion batteries by considering stress evolution, charging time and capacity utilization. Front. Struct. Civ. Eng. 2019, 13, 294-302. [CrossRef] 
92. Li, M.; Feng, M.; Luo, D.; Chen, Z. Fast Charging Li-Ion Batteries for a New Era of Electric Vehicles. Cell Rep. Phys. Sci. 2020, 1, 100212. [CrossRef]

93. Weiss, M.; Ruess, R.; Kasnatscheew, J.; Levartovsky, Y.; Levy, N.R.; Minnmann, P.; Stolz, L.; Waldmann, T.; Wohlfahrt-Mehrens, M.; Aurbach, D.; et al. Fast Charging of Lithium-Ion Batteries: A Review of Materials Aspects. Adv. Energy Mater. 2021, 11, 2101126. [CrossRef]

94. Han, J.-G.; Jeong, M.-Y.; Kim, K.; Park, C.; Sung, C.H.; Bak, D.W.; Kim, K.H.; Jeong, K.-M.; Choi, N.-S. An electrolyte additive capable of scavenging HF and PF5 enables fast charging of lithium-ion batteries in LiPF6-based electrolytes. J. Power Sources 2020, 446, 227366. [CrossRef]

95. Colclasure, A.; Tanim, T.R.; Jansen, A.; Trask, S.E.; Dunlop, A.R.; Polzin, B.J.; Bloom, I.; Robertson, D.; Flores, L.; Evans, M.; et al. Electrode scale and electrolyte transport effects on extreme fast charging of lithium-ion cells. Electrochim. Acta 2020, 337, 135854. [CrossRef]

96. Du, Z.; Wood III, D.L.; Belharouak, I. Enabling fast charging of high energy density Li-ion cells with high lithium ion transport electrolytes. Electrochem. Commun. 2019, 103, 109-113. [CrossRef]

97. Habedank, J.B.; Kraft, L.; Rheinfeld, A.; Krezdorn, C.; Jossen, A.; Zaeh, M.F. Increasing the Discharge Rate Capability of LithiumIon Cells with Laser-Structured Graphite Anodes: Modeling and Simulation. J. Electrochem. Soc. 2018, 165, A1563-A1573. [CrossRef]

98. Zeng, Y.; Chalise, D.; Lubner, S.D.; Kaur, S.; Prasher, R.S. A review of thermal physics and management inside lithium-ion batteries for high energy density and fast charging. Energy Storage Mater. 2021, 41, 264-288. [CrossRef]

99. Cai, W.; Yao, Y.-X.; Zhu, G.-L.; Yan, C.; Jiang, L.-L.; He, C.; Huang, J.-Q.; Zhang, Q. A review on energy chemistry of fast-charging anodes. Chem. Soc. Rev. 2020, 49, 3806-3833. [CrossRef] 